NATIONAL LABORATORY

\title{
Survey of Alternative Feedstocks for Commodity Chemical Manufacturing
}

\section{March 5, 2007}

\author{
Prepared by \\ Joanna McFarlane \\ Staff Scientist \\ Sharon Robinson \\ Industrial Technologies Program Manager
}

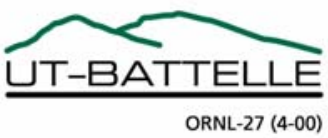




\section{DOCUMENT AVAILABILITY}

Reports produced after January 1, 1996, are generally available free via the U.S. Department of Energy (DOE) Information Bridge.

Web site http://www.osti.gov/bridge

Reports produced before January 1, 1996, may be purchased by members of the public from the following source.

National Technical Information Service

5285 Port Royal Road

Springfield, VA 22161

Telephone 703-605-6000 (1-800-553-6847)

TDD 703-487-4639

Fax 703-605-6900

E-mail info@ntis.gov

Web site http://www.ntis.gov/support/ordernowabout.htm

Reports are available to DOE employees, DOE contractors, Energy Technology Data Exchange (ETDE) representatives, and International Nuclear Information System (INIS) representatives from the following source.

Office of Scientific and Technical Information

P.O. Box 62

Oak Ridge, TN 37831

Telephone 865-576-8401

Fax 865-576-5728

E-mail reports@osti.gov

Web site http://www.osti.gov/contact.html

This report was prepared as an account of work sponsored by an agency of the United States Government. Neither the United States Government nor any agency thereof, nor any of their employees, makes any warranty, express or implied, or assumes any legal liability or responsibility for the accuracy, completeness, or usefulness of any information, apparatus, product, or process disclosed, or represents that its use would not infringe privately owned rights. Reference herein to any specific commercial product, process, or service by trade name, trademark, manufacturer, or otherwise, does not necessarily constitute or imply its endorsement, recommendation, or favoring by the United States Government or any agency thereof. The views and opinions of authors expressed herein do not necessarily state or reflect those of the United States Government or any agency thereof. 
Nuclear Science and Technology Division

\title{
SURVEY OF ALTERNATIVE FEEDSTOCKS FOR COMMODITY CHEMICAL MANUFACTURING
}

\author{
Joanna McFarlane and Sharon M. Robinson
}

Date Published: March 2007

Prepared by

OAK RIDGE NATIONAL LABORATORY

Oak Ridge, Tennessee 37831-6283

managed by

UT-BATTELLE, LLC

for the

U.S. DEPARTMENT OF ENERGY

under contract DE-AC05-00OR22725 



\section{CONTENTS}

\section{Page}

LIST OF FIGURES

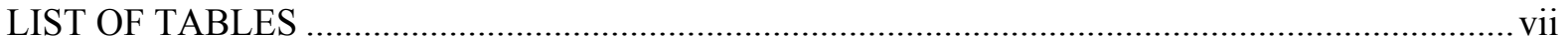

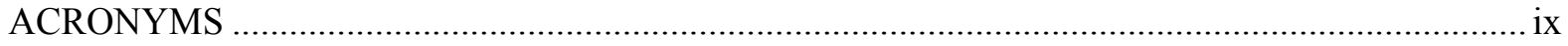

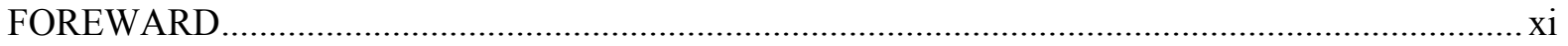

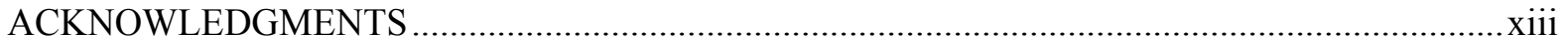

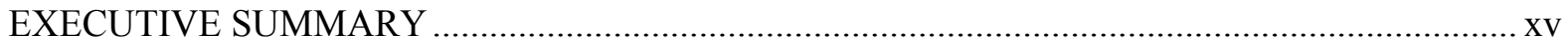

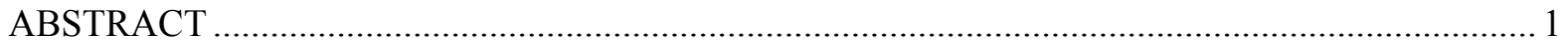

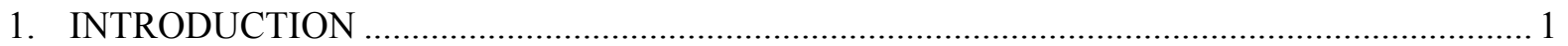

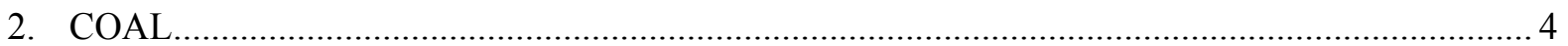

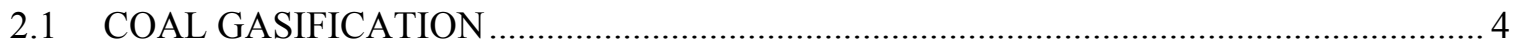

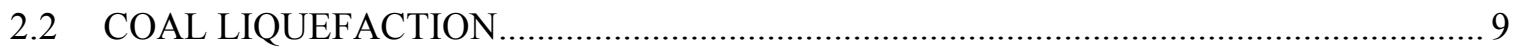

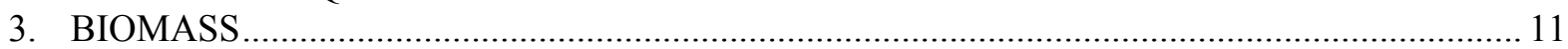

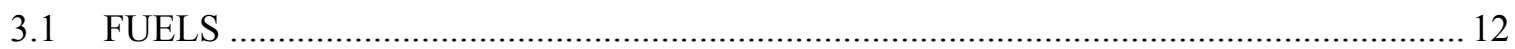

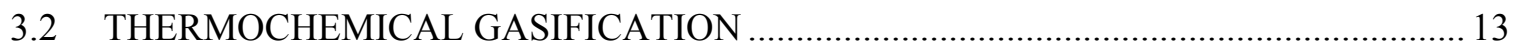

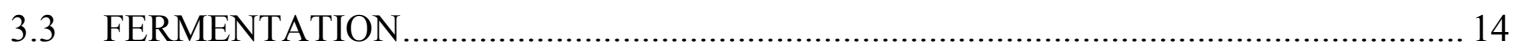

3.3.1 Products of Sugar Fermentation................................................................ 14

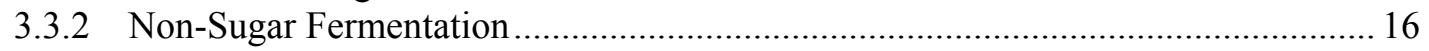

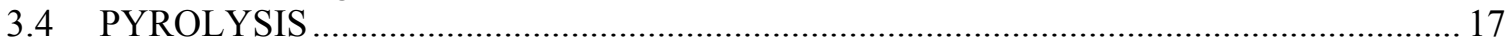

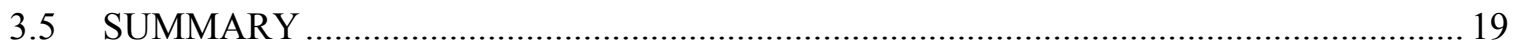

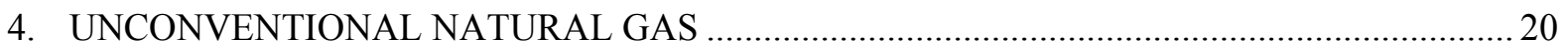

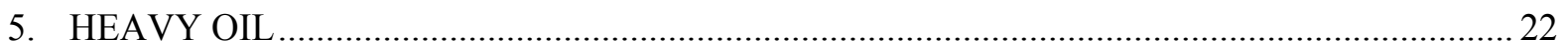

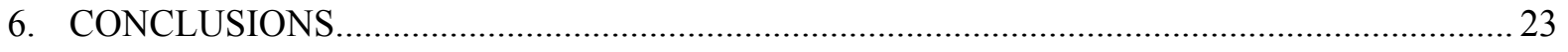

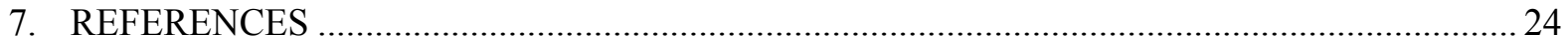

Appendix A: LARGE VOLUME CHEMICALS MANUFACTURED IN THE UNITED

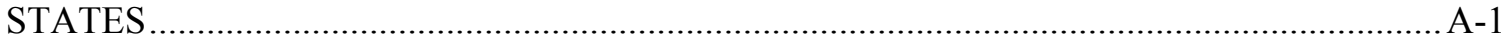





\section{LIST OF FIGURES}

Figure

Page

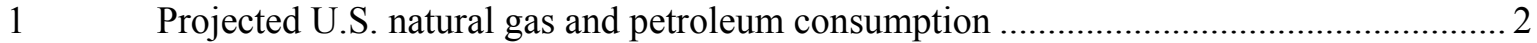

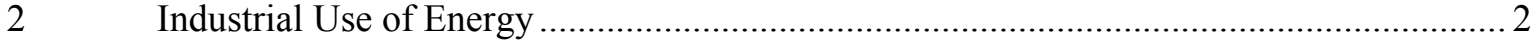

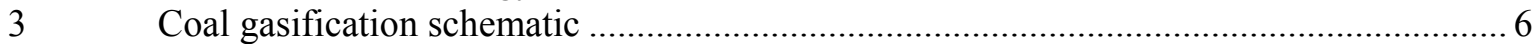

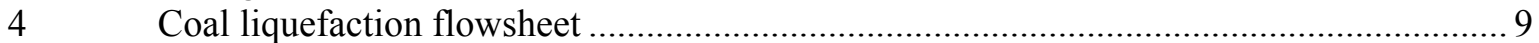

$5 \quad$ Priorities set by the Biomass Technical Advisory Committee...................................... 12

$6 \quad$ Syngas biomass gasification scheme as implemented by Choren ................................... 14

$7 \quad$ Flowsheet for the production of BioOil, DynaMotive Corporation.................................. 18 



\section{LIST OF TABLES}

Table

Page

1 Commodity chemicals considered for production from alternate feedstocks ................... 4

$2 \quad$ Top 12 products from sugar fermentation ............................................................. 15

3 Large volume chemicals manufactured in the United States ....................................... A-3

$4 \quad$ Specialty chemicals, chemicals with development potential ...................................... A-4

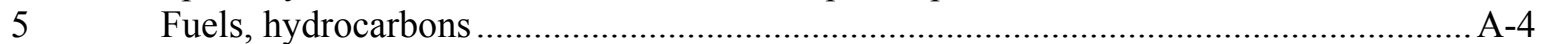





\section{ACRONYMS}

bcfd - billion cubic feet per day

BDC - Bitumen derived crude

CBP - Consolidated bioprocessing approach

CCS - Carbon capture and sequestration

CPP - Catalytic process pyrolysis

CTL - Coal to liquid

DCC - Deep catalytic cracking

DME - Dimethyl ether

DOE - US Department of Energy

EDS - Exxon donor solvent

EERE - Energy Efficiency and Renewable Energy

FCC - Fluidic carbon cracking

FT - Fischer Tropsch

GTL - Gas to liquid

$\mathrm{GW}_{\mathrm{t}}$ - Gigawatt thermal equivalent

HGO - Heavy gas oil

HTI - Hydrocarbon Technologies Inc.

IGCC - Integrated gasification combined cycle

ITM - Ion transport membrane

LNG - Liquified natural gas

MTO - Methanol to olefin

MTG - Methanol to gasoline

MTP - Methanol to polymer, Methanol to propylene

$\mathrm{MW}_{\mathrm{e}}$ - Metawatt electric equivalent

$\mathrm{MW}_{\mathrm{t}}$ - Megawatt thermal equivalent

ORNL - Oak Ridge National Laboratory

PDH - Propane dehydrogenation

SAGC - Steam assisted gravity drainage

SRC - Solvent refined coal

TCM - Trillion cubic meters.

TPD - Tons per day

WGS - Water gas shift 



\section{FOREWORD}

Recent high prices of conventional oil and natural gas have highlighted the fact that these commodities are not renewal and holdings are largely situated offshore in areas that are politically unstable. President G.W. Bush emphasized in his Jan 232007 state of the union address that "It is in our vital interest to diversify America's energy supply - and the way forward is through technology." The chemical industry is a large consumer of petroleum, comprising $4 \%$ of the total US energy consumption and $3 \%$ of the US natural gas consumption. Over half of that allocation goes to feedstock chemicals, 3.4 quads in 2005, 0.6 quads of that coming from natural gas, 1.4 quads coming from natural gas liquids, and 1.4 quads from heavy liquids*.

In collaboration with the Vision 2020 industry partnership, ORNL assessed the state-of-the-art of using alternative, renewable, and/or novel feedstocks (such coal; biomass; oil shale; tar sands; unconventional methane, i.e. "stranded" or "remote" sources, coal bed, and gas hydrates; etc) for large-scale chemical production. The focus was on commodity chemicals, with production greater than a million tons/year, rather than niche market chemicals or pharmaceuticals. The goals were

- to evaluate the energy savings potential of alternative feedstocks, exploiting possible cross linkages between chemical industry feedstocks and fuel

- to identify and define the technical barriers and research needs needed to implement alternative feedstocks, and to

- define potential candidate commercial processes to be considered for initial applications, including opportunities for feed substitution to make existing products in existing petrochemical units.

* Guide to the Business of Chemistry 2005, Chemicals Industry of the Future Annual Report 2004 



\section{ACKNOWLEDGMENTS}

The authors would like to thank the following Vision 2020 chemical industry collaborators for their assistance in preparing this report:

John Carberry - Dupont

Terri Grocela-Rocha - General Electric

Mark Jones - Dow Chemical Company

Frank Lipiecki - Rohm \& Haas Company

Joanna McFarlane - Oak Ridge National Laboratory (ORNL)

David Mobley - General Electric Company

Brendan Murray - Shell

Ravi Prasad - Praxair

Sharon Robinson - Oak Ridge National Laboratory (ORNL)

Jeff Siirola - Eastman Chemical Company

Cheryl Sabourin - General Electric Company

Clark Simmons - Innovene LLC

David Södeberg - BP

Tyler Thompson - Dow Chemical Company

Phillip Winkler - Air Products and Chemicals Inc.

Joe Zoeller - Eastman Chemical Company

J. Hiram Rogers provided assistance with technical editing. The work was funded through the US Department of Energy, partially through the Industrial Technologies program of the Office of Energy Efficiency and Renewable Energy, and partially through the Office of Fossil Energy. 



\section{EXECUTIVE SUMMARY}

The current high prices for petroleum and natural gas have spurred the chemical industry to examine alternative feedstocks for the production of commodity chemicals. High feedstock prices have driven methanol and ammonia production offshore. The U.S. Chemical Industry is the largest user of natural gas in the country. Over the last 30 years, alternatives to conventional petroleum and natural gas feedstocks have been developed, but have limited, if any, commercial implementation in the United States. Alternative feedstocks under consideration include coal from unconventional processing technologies, such as gasification and liquefaction, novel resources such as biomass, stranded natural gas from unconventional reserves, and heavy oil from tar sands or oil shale. These feedstock sources have been evaluated with respect to the feasibility and readiness for production of the highest volume commodity chemicals in the United States.

Sources of organic compounds, such as ethanol from sugar fermentation and bitumen-derived heavy crude are now being primarily exploited for fuels, rather than for chemical feedstocks. Overall, government-sponsored research into the use of alternatives to petroleum feedstocks focuses on use for power and transportation fuels rather than for chemical feedstocks. Research is needed to reduce cost and technical risk. Use of alternative feedstocks is more common outside the United States R\&D efforts are needed to make these processes more efficient and less risky before becoming more common domestically. The status of alternative feedstock technology is summarized below.

Coal: Substantial U.S. coal reserves make coal an attractive alternative to natural gas and petroleum. Historically research into coal gasification has been focused on energy fuels, and more recently on power production, with less emphasis on commodity chemicals production. For example, DOE's FutureGen project seeks to improve coal gasification for power production. Similar efforts to develop pathways for chemicals production using optimal catalysts and for process scale-up are needed to replace conventional petroleum. Coal gasification plants that produce transportation fuels and chemicals are in operation. Although large-scale facilities are present in South Africa and China, the penetration rates of these technologies in the US has been slow, due primarily to previously low prices for petroleum feedstocks. Research is needed to optimize chemical pathways from FischerTropsch hydrocarbons to commodity chemicals, as these pathways may be different from those derived from petrochemical feedstocks, and to improve efficiency, yield and economics. Other areas of concern are the variability in feedstock composition and the potential for impurities to poison catalysts.

Biomass: Thousands of years of innovations in agriculture have optimized crops for food and fiber production, but not for energy production. The recent development of biomass-ethanol for fuel production needed government support to become viable. In general, the fermentation of sugar from crops such as corn and sugarcane will provide oxygenated organics, but these are often small volume niche chemicals with limited potential for large scale manufacture. However, some bio-based chemicals that have potential for large scale manufacture include the carboxylic acids and glycols. Research topics being explored in the laboratory and on the pilot scale include: biomass gasification, fermentation of sugars, decomposition of cellulose, separation of lignin and other plant components, high temperature pyrolysis, and biorefining of wood and waste materials. Issues in the replacement of petroleum by biomass feedstocks include impurities, variabilities of feedstock composition, distributed supply, scalability and pathways for breakdown of cellulose. Although some large-scale chemicals production occurs as a byproduct of fuel production, widespread use of biomass feedstocks for commodity chemical manufacture will require sustained research and development in a variety of fields such as plant science, microbiology, genomics, catalysis, and chemical separations technologies. 
Stranded natural gas: Transportation of natural gas from isolated sources could best be effected by converting the light hydrocarbons to easily transportable liquids, such as methanol, in situ. Natural gas is used to manufacture methanol offshore, but production in the United States has been curtailed because of the high cost of natural gas. Methanol is a key building block chemical, and a methanolbased economy has touted as an alternative to a hydrogen economy. Technologies exist for methanol-to-olefin production that are ready for implementation. Pilot plants have been run in the United States and overseas. These processes will become viable depending on the prices of the feedstocks and oil, all of which are highly variable, as well as costs for transportation and storage.

Heavy Oil: Heavy oil, derived from unconventional sources such as tar sands in Canada and Venezuela has a higher aromatic content than conventional crude. The key aspect that needs to be addressed in the use of heavy oil for chemicals is the development of a ring opening catalyst to break down the polyaromatic tar compounds into smaller molecules. Oil shale in Colorado has the potential to be a large scale domestic supply of petroleum. Extraction technologies are currently being developed and tested, with the product of leading processes predicted to be sweet crude. Environmental issues, especially subsidence and protection of groundwater, are likely to be areas requiring further $R \& D$.

Over the last 30 years, there has been much activity in the development of alternative feedstocks, but little activity in bringing technologies to market. The delay in implementation rests on the economics of the process. The economic competitiveness of technologies such as integrated gasification combined cycle, IGCC, and gas-to-liquids, GTL depend on the current and predicted prices of oil and alternative feedstocks, and the costs for transportation and storage. A recent increase in the price of oil makes alternative processes more economically viable. However, conversion to use of alternative feedstocks requires a large investment of capital and is unlikely to occur when feedstock prices remain variable and unpredictable. Scale-up from successful pilot processes will be helped if feedstocks for the chemical industry can be coupled with power production or other needs. This requires communication and planning across sectors of the economy which do not currently collaborate closely. 


\begin{abstract}
Energy security and currently high prices for petroleum and natural gas have created interest in the US DOE and the US chemical industry to evaluate alternative feedstocks for the production of commodity chemicals. These feedstocks may come from plentiful resources used in non-traditional technologies, such as coal gasification and coal liquefaction; from unconventional reserves such as stranded natural gas and heavy oil from tar sands or oil shale; or from novel resources such as biomass. Because of recent interest in alternative fuels production, there are many recent reviews on the state of the art of alternative technologies. The use of alternative feedstocks for production of the highest volume commodity chemicals produced in the US has been evaluated in this report. Technical barriers for implementation have been identified. Current government-sponsored R\&D is focused on power generation or the production of transportation fuels. New pathways for commodity chemicals manufacture need to be developed using feedstock alternatives to petroleum and using sustainable manufacturing technologies.
\end{abstract}

\title{
1. INTRODUCTION
}

The U.S. must address growing environmental issues, supply issues, and increasing energy prices to meet energy and raw material demands for the future. Efforts to increase industrial costcompetitiveness, boost energy efficiency, increase productivity, increase energy security, and prevent pollution will require that traditional chemical feedstocks (petroleum and natural gas) be supplemented with materials that are abundant in the U.S. To address these issues, the development of alternative feedstock pathways for commodity chemical production is needed.

Development of alternative feedstocks is critical to reducing U.S. dependence on foreign oil, and maintaining the viability of the U.S. manufacturing industry. As shown in Figure 1, the manufacturing industry is the second largest consumer of oil and natural gas in the U.S. after transportation, accounting for $\sim 30 \%$ of the present total usage. The demand for transportation fuel is expected to account for $65 \%$ of the increase in total oil and natural gas demand by 2030 (up from 60 quads $\left(10^{15} \mathrm{BTU}\right)$ in 2003 to 80 quads in 2030). The manufacturing industry's use of oil and gas is expected to increase from 18 quads to 22 quads, accounting for $20 \%$ of the expected total increase. Efforts to both replace energy sources and reduce usage are needed to maintain a viable manufacturing base in the U.S. 


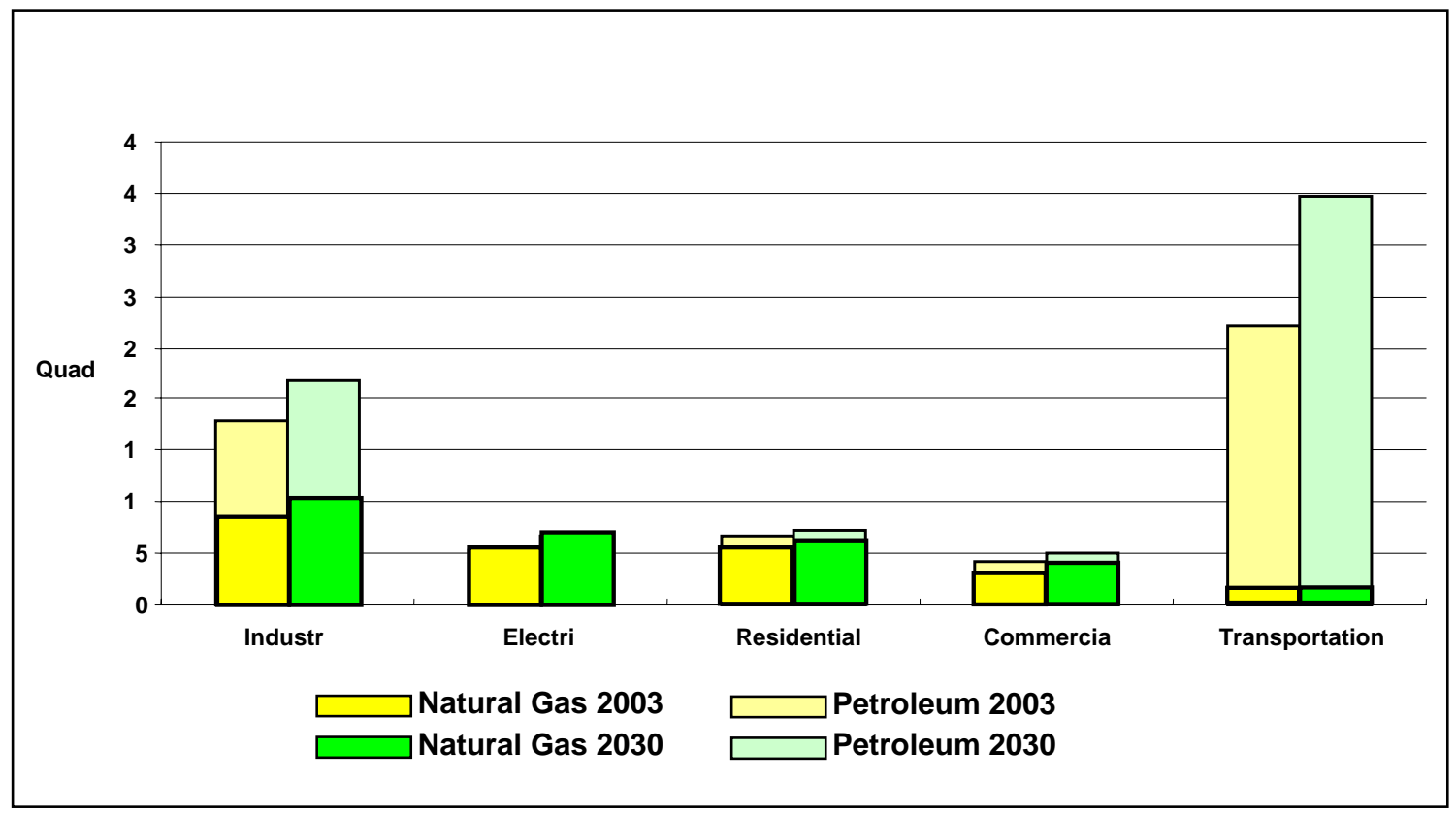

Fig. 1. Projected U.S. Natural Gas and Petroleum Consumption (Annual Energy Outlook 2006, Energy Information Administration, February 2006).

Within the manufacturing sector, the chemical industry is the largest user of natural gas and the second largest user of total petroleum as shown in Figure 2. The U.S. chemical industry used 6.4 quads of energy in 2004, $6.4 \%$ of the total U.S. energy consumption. The chemical industry is the single largest user of natural gas, accounting for $10 \%$ of all U.S. natural gas consumption. The industry uses energy, primarily petroleum, natural gas, and natural gas liquids, to supply heat and power for manufacturing processes as well as for raw materials used in manufacturing. Approximately $47 \%$ of the chemical industry energy usage was for fuel and power production, and $53 \%$ (3.4 quad equivalents) were used as feedstocks. Petroleum-based feedstocks used in manufacturing presently account for $3.4 \%$ of the total U.S. energy consumption and $2.5 \%$ of the total natural gas consumption. Several current DOE programs are addressing reductions in energy usage and replacement of fuels for transportation and power, but there are presently no major efforts to replace use of petroleum as raw materials used in chemical manufacturing.

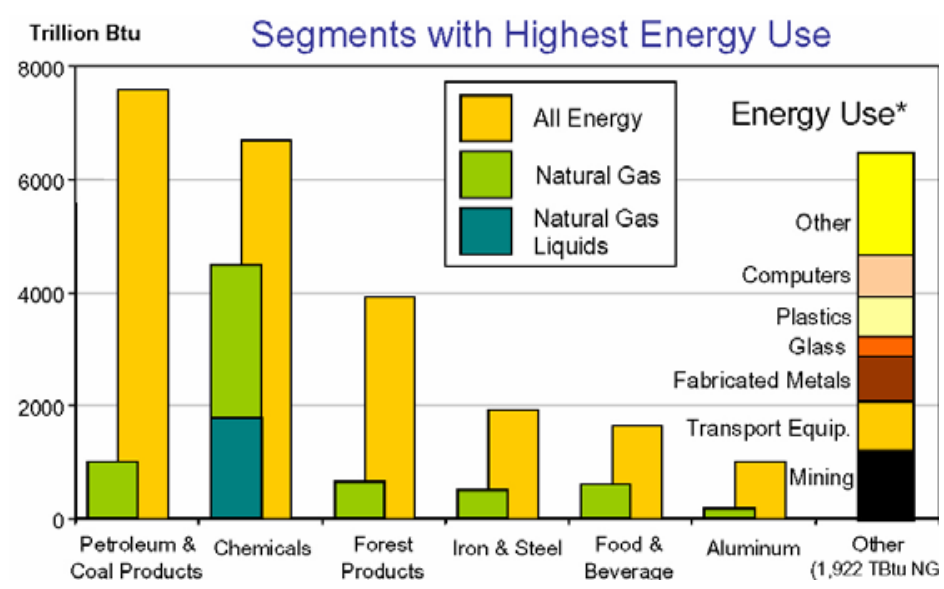

Fig. 2. Industrial Use of Energy (DOE ITP Save Energv Now) 
Petroleum, natural gas liquids, and natural gas account for $99 \%$ of the feedstock materials used by the chemical industry. Natural gas is predominately used to manufacture methanol and ammonia, and $70 \%$ of the U.S. olefins (particularly ethylene) production is based on natural gas liquids. As the U.S. supply of natural gas and natural gas liquids has decreased and prices have risen in the $2000 \mathrm{~s}$, production of these chemicals has been transferred overseas. In 2004 about $50 \%$ of the U.S. methanol, $45 \%$ of the ammonia, and $15 \%$ of the ethylene capacity were shutdown, and the percentage transferred overseas has increased since that date.

This report assesses the state-of-the-art of using alternative, renewable, and/or novel feedstocks for large-scale chemical production. These alternatives to conventional petroleum and natural gas include coal, biomass, unconventional natural gas, (including methane from "stranded" or "remote" sources, coal bed methane and gas hydrates), and unconventional oil derived from oil shale and tar sands.

The goal of this project was to provide a framework to identify needs for research investment in replacement of petroleum-based feedstocks that would generate savings in supply and cost, as well as increased energy security (Hirsch et al. 2006). Efforts are in place to produce $25 \%$ of industrial organic chemicals from biomass by 2025 (Ragauskas et al. 2006).

The aim of this project is to summarize the published literature to identify the potential of alternative feedstocks, and to review the state-of-the-art of the processes for conversion to chemical feedstocks. The level to which various process technologies have been developed and the penetration or adoption of these technologies will be addressed. Much of the information reported here comes from reports prepared for the National Commission on Energy Policy, in Nov. 2004 (Mann 2004, Williams 2004a and 2004b). Several other recent reviews exist, such as that done by Olah (2005) on the methanol economy.

Further study will be needed to:

- Identify and define the technical barriers and research needs needed to implement alternative feedstocks. These barriers and needs may be specific to the chemical industry, such as requirements for purity above that of the power industry. Other needs may be common to a broad-based use of alternative-feedstocks, such as the desire for a robust crop for biomass production.

- Define potential candidate commercial processes to be considered for initial applications, including opportunities for feed substitution to make products in existing petrochemical units.

- Explore cross linkages between chemical feedstocks and fuel/energy production. For instance, glycerol is a byproduct of biodiesel production. Because of this, the production of glycerol has increased dramatically, reducing the cost of production by economy of scale and outcompeting other means of production. Alternatively, costs for an alternative feedstock will increase if demand increases faster than supply, because of implementation of new technologies.

- Identify issues, such as security of supply, where one feedstock would be favored over another.

The focus of this report is on large volume organic chemicals, primarily those derived from natural gas or petroleum feedstocks. Chemicals that are derived from inorganic sources, such as sulfuric acid or chlorine, will not be included in this study. Table 1 below lists commodity chemicals of interest that could be produced with alternative feedstocks. These chemicals generally are those with volumes of production of at least 500 million - to over 2 billion lbs/yr. However, some specialty chemicals, and those with future potential or an underdeveloped market have also been considered, especially in 
the case of bio-based feedstocks (www.acs.org, Chemical Manufacturers Association 1998).

Table 1: Commodity chemicals considered for production from alternate feedstocks

\begin{tabular}{|l|l|l|l|}
\hline Chemical & Alternative source & Industry/end use & $\begin{array}{l}\text { Volume } \\
\text { (x10 } \\
\mathbf{1 9 9 7} \text { US } \\
\text { production }\end{array}$ \\
\hline $\begin{array}{l}\text { Olefins: } \\
\text { Ethylene } \\
\text { Propylene } \\
\text { Butadiene }\end{array}$ & $\begin{array}{l}\text { Gasification of coal, } \\
\text { biomass, } \\
\text { From methanol or ethanol }\end{array}$ & R-Cl, oxide, polymers & 24 \\
\hline $\begin{array}{l}\text { Aromatics: } \\
\text { Benzene } \\
\text { Toluene } \\
\text { Xylene }\end{array}$ & $\begin{array}{l}\text { Gasification from methanol } \\
\text { (gas-to-liquids) }\end{array}$ & Polymers/cyclohexane & 14 \\
\hline $\begin{array}{l}\text { Paraffinic } \\
\text { derivatives } \\
\text { MEG/MPG/MTO }\end{array}$ & $\begin{array}{l}\text { Glycerol from biodiesel } \\
\text { Tropsification/Fischer- }\end{array}$ & Antifreezes, Polyols, Polyesters & 2.0 \\
\hline Acetone & $\begin{array}{l}\text { Gasification of coal, } \\
\text { biomass, BTEX }\end{array}$ & Intermediate & 7.5 \\
\hline Formaldehyde & From methanol, CH CH $_{4}$ & Olefin, wood products & 4.1 \\
\hline
\end{tabular}

\section{COAL}

\subsection{COAL GASIFICATION}

Commodity chemicals can be produced through the gasification of coal. Because of the large domestic reserves of coal, this feedstock option is one of strongest for the United States in the long term (Katzer 2007). The technology associated with coal gasification is well understood, having been used in Germany in WWII (Becker 1981) and in South Africa to produce liquid fuels in combination with Fischer-Tropsch processing.

Gasification of coal for applications including production of chemical feedstock is already widely practiced worldwide, with 117 plants (385 gasifiers) $)^{\dagger}$ operating in 24 countries in 2004 . The majority of existing plants gasify coal (i.e., 49 percent of capacity provided by 22 plants), It is projected that coal also will be the feedstock of choice for most new capacity planned for installation between 2005 and 2010. Of that new capacity, coal is expected to feed 29 of 38 new plants, and 24 of those 29 coal plants will be located in China. At existing plants, a slight majority (37 percent of capacity at 81 plants) generates feedstock for chemical production, closely followed by Fischer Tropsch liquids production (i.e., 36 percent of capacity at 4 plants). Of the 38 new plants, 24 (63 percent of the total) will produce syngas for chemical feedstock. In terms of capacity, however, Fischer-Tropsch liquids

$\dagger$ This is the total number of pants with capacity exceeding $100 \mathrm{MW}$ electric $\left(\mathrm{MW}_{\mathrm{e}}\right)$ equivalent included in the world gasification survey as reported in USDOE (2002). These plants equaled a total capacity of over 25,000 $\mathrm{MW}_{\mathrm{e}}$, which equated with approximately 45,000 MW thermal $\left(\mathrm{MW}_{\mathrm{th}}\right)$ capacity. 
will be the dominant gasification product at 43 percent, and chemicals will come in second at 34 percent (BCS Inc., 2006).

Coal gasification is being used today for small scale chemicals production in the US and elsewhere. Williams (2004a, 2004b) indicates that in 2004 there were 366 gasifiers worldwide producing 42.7 $\mathrm{GW}_{\mathrm{t}} /$ year of syngas, $27 \mathrm{GW}_{\mathrm{t}} /$ year of that from coal. Other numbers give gasification production in $\mathrm{GW}_{\mathrm{t}}$ equivalents $\left(24 \mathrm{GW}_{\mathrm{t}} /\right.$ year chemicals, $23 \mathrm{GW}_{\mathrm{t}} /$ year electric, $14 \mathrm{GW}_{\mathrm{t}} /$ year synfuels). The U.S. currently accounts for 15 percent of world capacity. Seven of the U.S. plants currently operate on coal and/or petroleum coke, and three of those produce syngas as feedstock for the production of chemicals or fertilizer. In the U.S. there are firm plans to build six new plants that will run on coal and/or petroleum coke by 2010 , and additional coal-based IGCC plants may also be added to that mix (BCS Inc., 2006). Insitu coal gasification has been explored over the last half century (e.g., Chakrabartty and Selucky 1985), and has recently been promoted in the UK, the US, and Australia as a simpler and more environmentally friendly way to transform coal to electricity and chemicals (e.g., Green 2006, Ergo Energy 2002). Although simple in concept, underground coal gasification (UCG) is very dependent on the geology of the site, the heterogeneity of which has lead to difficulties in scaling a system up to a plant size.

The standard gasification process starts with the production of syngas in a gasifier (coal + steam $/ \mathrm{O}_{2}$ ) to give $\mathrm{H}_{2}+\mathrm{CO}$. Further catalysis assists the reaction of $\mathrm{CO}$ to $\mathrm{CO}_{2}$ in presence of water to produce $\mathrm{H}_{2}$ (e.g., Dakota gasification). Ammonia can be produced, and methanol, alcohols, and aldehydes, by oxosynthesis. A Fischer-Tropsch process can be used to produce alkanes, which are building blocks for many large-volume chemicals.

Currently, three gasification technologies dominate the market (i.e., account for 94 percent of the 2004 total capacity). These are the Sasol Lurgi (41 percent), GE Energy (34 percent), and Shell (19 percent) technologies (see Appendix A). That percentage distribution is expected to change by 2010 , however, with Shell growing to produce 43 percent of syngas capacity, and Sasol Lurgi dropping to 27 percent. The GE Energy and Conoco-Phillips technologies are planned for use at 12 of the planned new plants (i.e., six plants each). Thus, oxygen-blown, high-temperature, slagging entrainedflow technology will dominate the near-term growth in gasification projects. BCS Inc., 2006

Numerous syngas production technologies are described and illustrated at the National Energy Technology Laboratory web site http://www.netl.doe.gov/technologies/coalpower/gasification/index.html. A generic oxygen-blown gasification system is illustrated in Figure 3 and comprises the following main steps:

(i) Reaction with oxygen or steam at $70 \mathrm{~atm}$.

(ii) Quench with water to remove particles and cool syngas

(iii) Water-gas-shift reaction (WGS) to produce $\mathrm{H}_{2}$ and $\mathrm{CO}_{2}$

(iv) Physical solvents remove $\mathrm{H}_{2} \mathrm{~S}$ and $\mathrm{CO}_{2}$ simultaneously. Solvents are recovered by depressurization. $\mathrm{H}_{2} \mathrm{~S}$ is converted to sulfur in a two step process by first heating in oxygen to produce $\mathrm{SO}_{2}$, which then reacts further with $\mathrm{H}_{2} \mathrm{~S}$ to produce $\mathrm{S}$ and steam. 


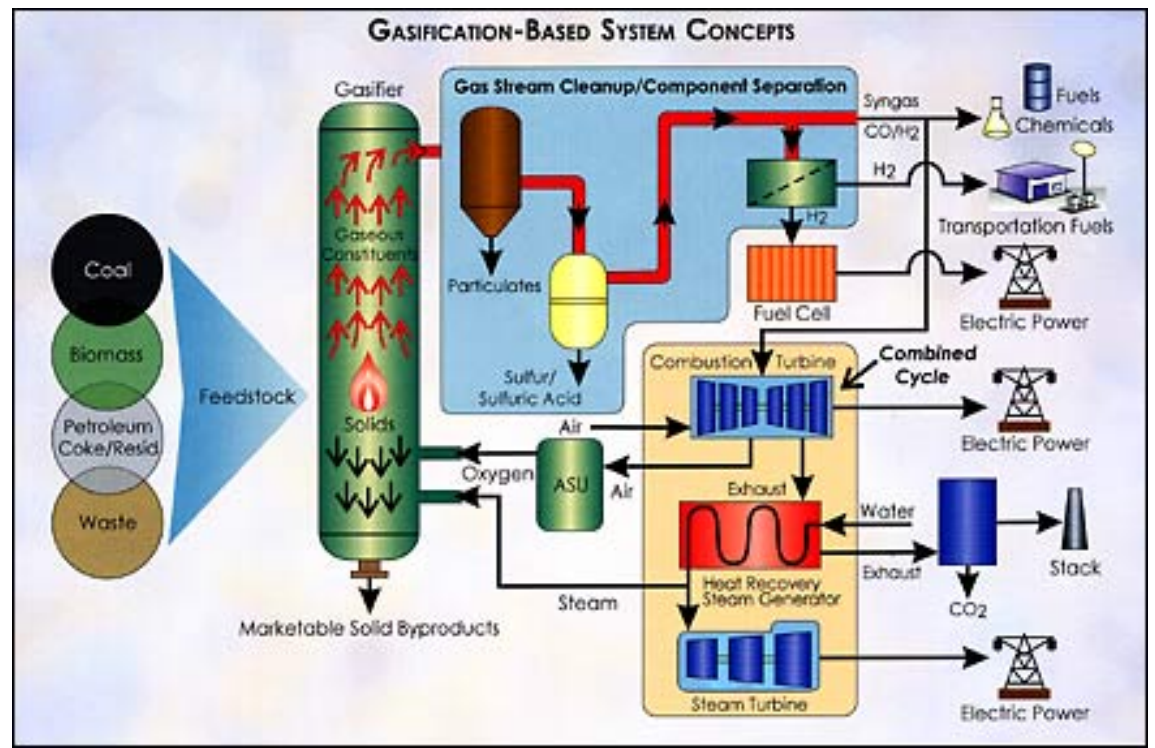

Fig. 3: Coal Gasification Schematic. (Source: USDOE http://www.fossil.energy.gov/programs/powersystems/gasification/howgasificationworks.html)

Modern gasification technologies for chemicals production that have been developed in the US are:

- $\quad \boldsymbol{E}$ Gas - purchased by Conoco Phillips - strategic alignment with Fluor

- Shell (Gasifier http://www.gasification.org/Docs/2005 Papers/05CHHO.pdf),

- $\boldsymbol{G E}$ Gasifier (used to be Chevron Texaco)

Gasification facilities have been built based on the technologies listed above. One successful example of this is Eastman Gasification Services located at Kingsport TN. This facility produces all of the acetic anhydride and acetic acid needed for in-plant production. The facility has reported a reliability of $97.7 \%$ for the production of $80,000 \mathrm{gal} / \mathrm{d}$ of methanol (US DOE 1997). Another facility is the Great Plains Synfuels plant in Beulah ND that produces 7 millions gallons per year of naphtha and 33 millions pounds per year of phenol (http://www.Dakotagas.com). Recent developments of gasification at petroleum refineries and chemical plants for ammonia production and industrial polygeneration (chemicals along with electricity) have been reported (Simbeck 2001). The claim is that syngas from residuals is less costly than reformation of methane on a lifecycle basis.

DOE is actively supporting the development of coal gasification for electricity production not only because of feedstock issues, but also as a means to permit carbon capture. Coal integrated gasification combined cycle (IGCC) technology was successfully demonstrated between 1984 and 1989 at Cool Water, California, in the United States. Since then, the following IGCC plants based on oxygen gasification of coal have been built (with subsidy support):

- The 250 MWe Demkolec plant at Buggenum, The Netherlands (Shell gasifier, Siemens gas turbine), started up in January 1994; (only 43\% capacity factor at first because of integration between gas turbine and air separation unit) (de Lange et al. 2001).

- The 262 MWe Wabash project in Indiana [E-Gas gasifier (now ConoccoPhillips), GE gas turbine), started up in October, 1995;

- The 253 MWe Tampa Electric project in Florida [ChevronTexaco gasifier (now GE), GE gas turbine), started up in September 1996; and

- The 310 MWe ELCOGAS project in Spain [Prenflo gasifier (now joint with Shell), Siemens gas turbine)], started up in December 1997 (Coca et al. 1998). 
Given the success of IGCC for electricity production at Cool Water, Williams (2004a, 2004b) comments on why gasification has not become an industry standard for coal conversion into power and chemicals. The primary reasons suggested by Williams and reiterated by Katzer (2007) are:

- the low costs of petroleum and natural gas when the project was completed in the mid-1980s,

- reliability concerns,

- installation cost (new technologies must be cheaper than current methods to justify the capital investment), and

- cultural mismatch and institutional challenges

- institutional challenges

- Williams asserted that promotion by the public sector or federal government involvement will be needed for widespread implementation of coal gasification. Risk sharing arrangements are needed - because power producers are not comfortable with new technology in the current economic climate. Benefits, such as low pollutant emission, reduced solid waste management, and oil supply/security issues are of public rather than private benefit.

- There is an argument that generators of power through gasification are mainly focused on competition with traditional coal/steam electric, and may not be amenable to the diversion of syngas to chemical production. However, this suggestion has been refuted by chemical industry representatives that suggest that symbiotic cogeneration agreements can be fostered, with chemical manufacture occurring during off-peak hours of electricity production.

- Williams' report also focused on the engineering challenge of carbon capture because of the large quantities of $\mathrm{CO}_{2}$ produced. Use of captured $\mathrm{CO}_{2}$ in a chemical plant or directly marketed is currently not economically feasible. However, captured $\mathrm{CO}_{2}$ can be used for enhanced oil recovery as demonstrated in the cooperation between Dakota Gasification and EnCana, where $\mathrm{CO}_{2}$ is piped across the Canadian border to enhance recovery from aging wells in Weyburn SK. The MIT study headed by Katzer (2007) gives calculations that $\mathrm{CO}_{2}$ production rates for chemicals (FischerTropsh liquids, methanol and natural gas) derived from coal gasification are actually significantly higher than if the chemicals were synthesized from traditional petroleum sources if carbon capture and sequestration technologies are not employed. However, the same authors also estimate that CCS costs for coal gasification associated with chemicals production are a third of those for IGCC alone.

In general, coal gasification technologies are mature and primarily it is economic issues that have delayed full scale implementation. However, most government-directed research effort has focused on electricity generation and production of transportation fuels, rather than developing pathways for the production of commodity chemicals. There are technical issues in gasification when specifically targeted towards chemical manufacture.

1. Coal type (lignite, bituminous, or sub-bituminous) is expected to affect the efficiencies and economics of gasification. Coal is plentiful in the US (250 yr supply at current consumption in the US or 270 billion tons (Energy Information Administration). However, gasification efficiencies are lower and costs higher for sub-bituminous coal because of high moisture and ash content, and about $40 \%$ of US coal is sub-bituminous coal from the Powder River Basin. Because any organic material can be gasified, existing gasifier designs can be adapted to use any type of coal as gasifier feed. Thus, coal characteristics do not offer insurmountable obstacles to its use for syngas production as a first step to chemicals or fuel production, but instead simply drive the economics of that use (BCS Inc., 2006). 
2. Minor impurities in coal that do not impact power generation, may affect chemical manufacture and byproduct formation. For instance, impurities such as alkalis may poison catalysts used in chemical production, but do not affect power production.

3. The development of a system for process control that can handle changes in syngas end use in one plant, perhaps on an hourly, daily, monthly, or yearly basis is needed. These variations may include changes in feedstock composition or end product requirements.

4. Gas separations are important. Ion transport membranes (ITM) may be used for gas phase separations in place of the current cryogenic-based separations, not only for impurity removal but also for chemical synthesis.

5. The economics of Fischer-Tropsch will depend on the product desired and the $\mathrm{H} / \mathrm{C}$ ratio from the syngas, which is not necessarily the same as for fuels production. For example, analysis by Olah (2005) on the use of $\mathrm{H}_{2}$ in syngas to produce methanol shows heat losses in the production of $\mathrm{H}_{2}$ in syngas of up to $20 \%$ of the total energy input to the system.

6. Environmental considerations will affect the economics of gasification and liquefaction. For example, emissions of particulates, $\mathrm{SO}_{\mathrm{x}}, \mathrm{NO}_{\mathrm{x}}$, mercury and other heavy elements should be reduced with the use of advanced technologies, because gasification and liquefaction have the potential to remove sulfur and mercury more effectively than remediation of flue gas from power plants. Carbon capture as a byproduct may assist the economics of gasification for chemicals manufacture. For example the proximity of the Dakota gasification plant to injection well sites allows sequestration of $\mathrm{CO}_{2}$, improving the economics of both the gasification plant and the gas field. $\mathrm{CO}_{2}$ may also be used as a reagent to produce liquid fuels, by reaction with $\mathrm{H}_{2}$ to produce $\mathrm{CH}_{4}$.

7. Technologies for the cofiring of multiple feedstock inputs need to be developed, such as a mixture of coal and biomass, for process optimization.

Because the price of petroleum dropped dramatically at the end of the $20^{\text {th }}$ century, gasification technology became uneconomical. Hence, there are minimal research funds currently directed by DOE Fossil Energy towards chemical feedstock production from coal, although research into gasification itself dates back to the 1920's, with a fairly significant effort in the 70's. The effort reached a low ebb before the 1990's start up of pilot scale operations. One example of a pilot scale development for production of chemicals was the piggybacking production of dimethyl ether and electricity (International Dimethyl Ether Association). In addition, a pilot combined-cycle coal gasification project is currently being evaluated for Gilberton, PA (ref DOE/EIS-3057). The primary focus of this facility is to gasify waste coal for electricity production and liquid fuel manufacture, the latter through Fischer-Tropsch processing of the syngas. The Gilberton plant is not designed for sequestration of $\mathrm{CO}_{2}$, but this functionality could be added later.

Technological options for converting coal into chemical feedstock are available and proven. The technology of gasification for power production is reasonably mature, http://www.fossil.energy.gov/programs/powersystems/gasification/, http://www.gasification.org/Presentations/2005.htm. Gasification of coal for chemicals production should be possible in 10 years, but requires $R \& D$ efforts to understand the role of control in optimization of the gasification process, effect of impurities, and handling of waste, particularly heavy metals. Small-scale gasification facilities are producing chemicals in the US, but replacement of commodity chemical production on the scale and breadth of current petrochemical plants is not immediately feasible. 


\subsection{COAL LIQUEFACTION}

Coal can also be liquefied directly, without going through a syngas step. This process is termed "coalto-liquid" or CTL, and is a reasonably mature technology (Research Reports International 2006). Direct liquefaction was first patented in 1913 and a commercial plant was established in the UK in 1935 to produce gasoline from coal and creosote. Early direct liquefaction involved dissolution of the coal in a solvent without use of a catalyst. After the war, there was a hiatus in the development of liquefaction technology until the 1960's, when a number of processes were investigated mainly in the US. These processes, the Solvent Refined Coal SRC-I and SRC-II, as well as the Exxon Donor Solvent Process (EDS) and H-coal have been recently reviewed (Research Reports International 2006). Modern liquefaction uses coal heating under pressure (up to $470^{\circ} \mathrm{C}, 200 \mathrm{bar}$ ) and hydrogenation where hydrogen is added to a coal-water slurry. The slurry increases the $\mathrm{H} / \mathrm{C}$ ratio to a crude oil level and removes impurities such as sulfur, nitrogen, and oxygen. Coal liquefaction has been reviewed by United Kingdom Department of Trade and Industry (1999), in a paper that gives advantages and disadvantages of the technology.

Currently, coal liquefaction technology is of particular interest to areas of the world with large deposits of coal, in Japan, China, India, Germany, the Philippines and South Africa. A full scale production facility to produce is being built in China (at Shenhua in Inner Mongolia province) for direct liquefaction of coal to transportation fuels, to yield $50,000 \mathrm{bbl} /$ day or one million tons of gasoline and diesel fuel per year starting in 2007 (www.htinj.com). The Shenhua plant uses a process licensed from Hydrocarbon Technologies Inc. (HTI) based on the original H-coal process, and is representative of a single-stage liquefaction process.

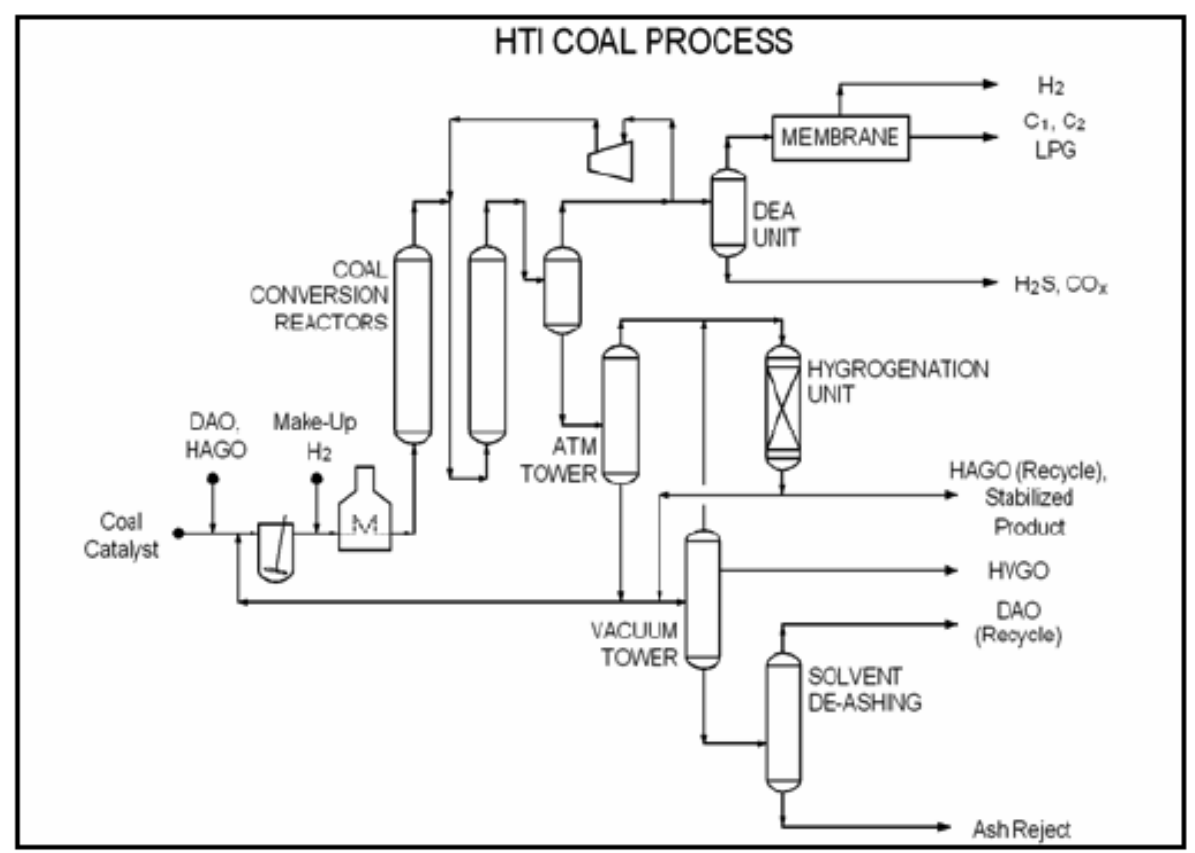

Fig. 4. Coal Liquefaction Flowsheet (Shenhua Group Corporation).

Recent developments in coal liquefaction are mostly based on the pre-World War II technologies, 
with the exception being a process developed by Conoco based on coal dissolution in molten zinc chloride. As a response to the oil crisis in the 1970's, two-stage liquefaction was developed, which separated coal dissolution and hydrogenation. Details on a number of two-stage liquefaction processes are given in Research Reports International (2006). Experience from coal liquefaction has indicated that the areas that pose the most risk to implementation on a large scale include the handling of liquids with a high load of solids that can cause mechanical difficulties in the plant. Waste handling is also an issue because of emissions of trace contaminants, such as mercury, that need to be quantified and regulated, handling of reduced sulfur byproducts, and polyaromatic hydrocarbon residues that are carcinogenic and so cannot be disposed of easily.

An advantage of coal liquefaction over gasification is the thermal efficiency of fuel production, with the former being 60-70\% and the latter no higher than 55\% (Research Reports International 2006). Product compositions are also different, with the direct process being skewed towards lower cetane fuels, and a higher aromatic content. The use of coal liquefaction for production of chemical feedstocks has not been discussed much in the literature, although the production of lower specific gravity hydrocarbons generated from coal gasification should be more easily be adapted to prevalent petrochemical-reaction pathways to commodity chemical production.

Carbonization and pyrolysis are the oldest direct methods of production of liquids from coal, involving heating of the coal and capture of volatilized liquids leaving a char reduced in hydrogen. The amount of liquid generated is small, less than $20 \%$, and the quality is poor being a complex blend of chemicals with water contamination. Although this technology was investigated in the US in the 1980's for the production of chemical feedstocks, it has been abandoned because of engineering difficulties. Because of the greater efficiency of processes such as the HTI technology illustrated above, these earlier methods are not being considered for chemicals production.

Co-processing of coal and a non-coal liquid hydrocarbon has also been considered, in particular for heavy oil. Co-processed feed has the advantage that recycled solvents are not required, and is a method of facilitate refining of heavy oil. More information on heavy oil will be given later in the report. Although a pilot plant was run in the US in Lawrenceville NJ from 1974 to the 1990's, the economics of the process depend on the cost of the unconventional hydrocarbon feedstock in comparison with petroleum. As with all of the coal liquefaction technologies discussed above, the focus of the program was to make gasoline and diesel fuel, although natural gas $\left(\mathrm{C}_{1}, \mathrm{C}_{2}, \mathrm{C}_{3}\right)$ and $\mathrm{NH}_{3}$ were also produced. 


\section{BIOMASS}

Use of biomass to make biofuels such as ethanol and biodiesel, is of great interest in the United States and elsewhere. Biofuels provide energy security, support local agriculture, and reduce net emissions of $\mathrm{CO}_{2}$ to the atmosphere (e.g., US DOE EERE 2005). The use of biomass to make chemicals has received less public attention to date. Chemical manufacturers currently use biomass to make organic acids, textile fibers, polymers, adhesives, lubricants and greases, and soy-based inks at a rate of 12.4 billion pounds per year (Biomass Technical Advisory Committee 2003). But even so this represents a small fraction $(\sim 5 \%)$ of the potential $>200$ billion-pound market. The Committee outlined the means to increase chemical production from Biomass in a "Roadmap for Biomass Technologies in the United States" (2003). The Biomass Technical Advisory Committee report highlighted research needs in three areas: biomass feedstock production, processing and conversion, and product use and distribution. In contrast, the present study focuses on processing and conversion technologies for chemicals production, as distinguished from fuel (i.e., ethanol and biodiesel) production.

Biorefining is the name given to the use of biologically derived feedstocks for chemicals manufacture. Advances in biorefining have been recently presented by representatives from industry, academia, and government at a special biorefining session of the American Chemical Society Conference Aug 28-Sept 1, 2005, Washington DC (http://oasys2.confex.com/acs/230nm/techprogram/S18624.HTM, http://oasys2.confex.com/acs/230nm/techprogram/S16333.HTM). The biorefinery concept generally involves feeding biomaterials, along with waste oils and other carbon-based materials, into steam or catalyst crackers to make chemicals. Alternatively, these feedstocks may be hydroprocessed directly. Mills are used to process biomass (corn, pulp) to produce carbohydrates, oils, lignin, and fuel compounds. Once broken down, fermentation will produce alcohols from sugars and starch.

Biorefining feedstocks are crops, waste plant or animal material, and recycled fibers. Eventually, biorefining will not only utilize the starch or sugar component of biomaterials, but also consume lignin, hemicellulose, and cellulose, in value-added processes beyond the current practice of burning these materials for fuel. Novel applications for biorefineries were presented at the 2005 ACS session on biorefining. One example was the bioconversion of sugars to produce polyols (building block chemicals). For instance, International Polychemicals has joined with Global Biochemicals of China to construct a 10,000 MT facility glycol facility in China, with a 200,000 MT facility under development. Conversion of vegetable oils to lubricants, hydraulic fluids and monomers, is another example of biorefining. 
Crosscutting Benefits of Processing and Conversion R\&D

\begin{tabular}{|l|c|c|c|}
\hline \multicolumn{1}{|c|}{ Major R\&D Needs } & $\begin{array}{c}\text { Biofuels } \\
\text { Impact }\end{array}$ & $\begin{array}{c}\text { Biopower } \\
\text { Impact }\end{array}$ & $\begin{array}{c}\text { Bioproducts } \\
\text { Impact }\end{array}$ \\
\hline Thermochemical Conversion: & $\mathrm{L}$ & $\mathrm{L}$ \\
- Co-Firing & $\mathrm{L}$ & $\mathrm{H}$ & $\mathrm{L}$ \\
- Direct Combustion & $\mathrm{L}$ & $\mathrm{H}$ & $\mathrm{L}$ \\
- Gasification & $\mathrm{L}$ & $\mathrm{H}$ & $\mathrm{M}$ \\
- Anaerobic Fermentation & $\mathrm{L}$ & $\mathrm{H}$ & \\
- Modular Systems & $\mathrm{L}$ & $\mathrm{H}$ \\
- Pyrolysis & $\mathrm{H}$ & $\mathrm{H}$ \\
\hline Bioconversion: & $\mathrm{H}$ & $\mathrm{M}$ \\
- Physical/Chemical Pretreatment & $\mathrm{H}$ & $\mathrm{M}$ & $\mathrm{H}$ \\
- Fractionation and Separation & $\mathrm{H}$ & $\mathrm{M}$ \\
- Residual Solids and Liquids & $\mathrm{H}$ & $\mathrm{M}$ & $\mathrm{H}$ \\
- Chemical/Enzymatic Conversion & $\mathrm{H}$ & $\mathrm{M}$ & $\mathrm{H}$ \\
- Catalytic and Chemical Conversion & $\mathrm{H}$ & $\mathrm{M}$ & $\mathrm{H}$ \\
- Inhibitory Substances & $\mathrm{H}$ & $\mathrm{M}$ & $\mathrm{H}$ \\
- Separation and Purification & $\mathrm{H}$ & $\mathrm{M}$ & $\mathrm{H}$ \\
- Biomass Fermentation and Hydrolysis & $\mathrm{H}$ & $\mathrm{H}$ & \\
- Syngas Fermentation & & $\mathrm{M}$ & $\mathrm{H}$ \\
\hline Biorefinery Integration & & & \\
\hline
\end{tabular}

H - High impact; M - Medium impact; L - Low impact

Fig. 5: Priorities set by the Biomass Technical Advisory Committee. These processes were reviewed in the "Roadmap for Biomass Technologies in the United States" (2003).

The focus for this report is to survey the development of biorefinery technologies for commodity chemical production. Three pathways for the extraction of chemicals from biomass will be examined: thermochemical gasification (or conversion), fermentation, and pyrolysis. The results of the Biomass Technical Advisory Committee's impact assessment of processing and conversion R\&D need areas are summarized in Figure 5. The analysis suggests major benefits to come from research into bioconversion and biorefinery integration. The Biomass Technical Advisory Committee was also optimistic about the timeframe for deployment of biotechnology, with the following large-scale technologies being implemented in the next 4-10 years: 100 TPD gasification, and 200,000 lbs per day black liquor production from wood products.

\subsection{FUELS}

The conversion of biomass to produce transportation fuel has received the recent attention from the DOE Biomass Program (EERE). The Biomass Program supports The President's National Energy Policy, Biomass R\&D Act of 2000, and the Farm Security and Rural Investment Act of 2002.

Biorefining has been embraced by Brazil, which has had a concerted effort over the last 30 years to home-grow its fuel for automobiles. The economics of Brazilian biorefining, using sugar from sugarcane to produce ethanol, versus the US approach of ethanol from corn, have been reviewed by Gallagher and coworkers (2006). The authors state that the production of ethanol from wet and dry milling would be cost competitive in both countries, providing that no trade tariffs were imposed. Bioprocessing of corn to produce ethanol, as practiced in the US, can either be done by wet-milling or dry-milling. The dry process gives ethanol only. The wet-milling produces gluten feed, gluten meal, and corn oil, as well as ethanol. In spite of additional expenses incurred for separations equipment 
and operation, these byproducts can be sold to improve the economics of ethanol production. Wet mills are large, and generally require a coal-fired plant to operate, where as dry mills ( $40 \mathrm{M}$ gal) are smaller, and use natural gas. The byproduct of sugarcane processing is bagasse, which can be burned for fuel, providing sufficient energy to run the processing plant.

Hammerschlag 2006 reviewed the bioprocessing of starch and cellulose to produce ethanol, and investigated the energy balance between inputs, farming costs, and energy output. In all cases, starch-based ethanol was more energy efficient than gasoline, and in most cases ethanol showed a net positive energy output. Ethanol production from cellulose and hemicellulose could be even more energy efficient than ethanol produced from starch, but there are large uncertainties in the calculation because the technology is much less developed.

Production of biodiesel (fatty acid methyl esters) from feed and biomass residues is of interest particularly in the developing world. Petrobras Brazil has developed processes for manufacturing diesel directly from castor beans, or from the esterification of castor bean oil. An alternative to fermentation, use of reactive distillation to produce esters of dibasic acids takes advantage of differences in volatility to give high purity products.

Biorefining becomes more cost effective when coupled with production of food, feed, power, and industrial and consumer products, and also has the advantage of reducing waste. One example of increased effectiveness is from a Danish plant, Grenaa, in which coal is burned for a straw pulping process, in tandem with ethanol production (Nikolaisen et al. 1998). For the best chance of success in the near term; however, biorefining must be operated on a small scale - in comparison with a petroleum refinery - relying as it does on a distributed supply of feedstock materials.

The production of bio-fuels will have a direct impact on the chemicals industry. For example, glycerine produced in Tavaux, France as byproduct of biodiesel manufacture, will supplant propylene as a feedstock in the production of epichlorohydrin en route to epoxy resins. Other chemical companies are taking advantage of similar opportunities (Chemical and Engineering News 2006).

\subsection{THERMOCHEMICAL GASIFICATION}

Syngas for commodity chemical production can be derived from biomass as coal. An example of the thermal gasification process for biomass is shown in Figure 6. Issues such as the production of clean syngas via biomass thermochemical processing are similar to issues associated with coal gasification. Gasification of biomass can take place under slightly milder conditions than coal gasification ( 800 to $1,000^{\circ} \mathrm{C}$ at $20-30$ bar instead of $1,400^{\circ} \mathrm{C}$ at 20 to 70 bar). Biomass (feedlot and chicken litter) can also be combined with a coal-syngas feedstock (Priyadarsan et al. 2004, 2005).

Black liquor gasification is being conducted on a US DOE -funded pilot scale at the University of Utah Institute for Combustion and Energy Studies

http://www.eng.utah.edu/ whitty/utah_blg/index.shtml. Black liquor is the lignin-based material that is produced during the pulping of paper. The University of Utah project has two separate units, a pressurized fluidized bed steam reformer and an entrained flow gasifier (under construction for 2006 start up).

Some pretreatment issues are unique to gasification of biomass. Biomass has a large water content that must be removed before gasification; the Choren process (www.choren.de) requires that starting 
material contain less than 35\% water. Biomass components (alkali metals, halides, sulfur compounds, and tars) have a significant potential to poison downstream noble metal catalysts used in production of syngas and chemicals (Raguaskas et al. 2006). Technologies have been developed to handle these impurities, but they add to the complexity and cost of the gasification process.

In addition, because production of biomass requires a large land base, feedstocks are diffuse, and manufacturing is distributed (e.g., forest pulp mills). Hence, innovative methods, such as feedstock densification or on-site drying prior to shipping, will be required to achieve economies of scale.

Many of the topics identified by the Biomass Technical Advisory Committee (2003) as those needing to be researched in thermochemical processing were also relevant to the use of biofuels in electricity production. The Committee also noted that scalability from small scale to industrial scale is not well understood for thermochemical conversion, and requires developments in analysis of costs, performance and emissions.

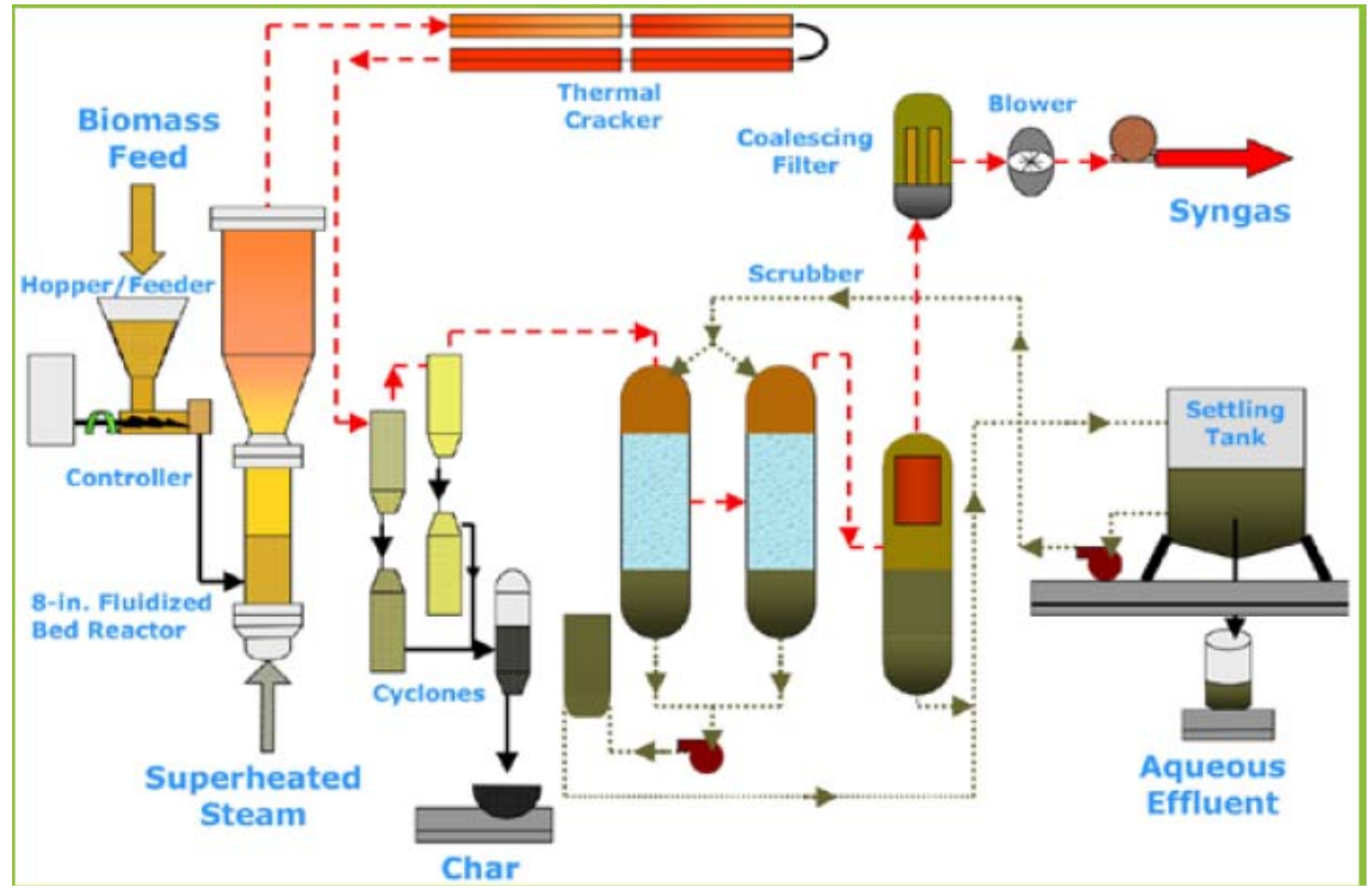

Fig. 6: DOE Thermochemical Users Facility, TCUF. http://www.nrel.gov/docs/fy04osti/33817.pdf. (DOE EERE 2003).

\subsection{FERMENTATION}

\subsubsection{Products of Sugar Fermentation}

A second pathway of use of biomass for production of chemical feedstocks is through fermentation. The fermentation of sugars has been the focus of much recent investigation because of US DOE support. The top 12 target products (Table 2) from sugar fermentation from biomass were chosen from 300 candidates by the PNNL/NETL/EERE roadmap committee based on the following criteria:

- functional groups that give rise to building block chemicals, 
- alignment with petrochemical pathways,

- availability of chemical data and market data,

- reliable property information,

- performance of production from sugar fermentation, and

- the industrial experience of authors.

The roadmap group first grouped chemicals into direct replacements for petroleum-based feedstock, novel building blocks, or intermediates. The chemicals were also classified from C1-C6 and evaluated for functional groups and reactivity. Commodity chemicals were excluded from the list because at the time of the study biomass production was not cost competitive with other alternative technologies. For this reason methanol was eliminated from consideration. The most promising building block chemicals from sugar fermentation identified by this process are listed in Table 2. While the production volumes of diacids and itaconic acid currently do not compare with the top ranked commodity chemicals listed in Table 1, these specialty chemicals have the potential for large scale development, and so are of particular interest to the chemical manufacturing community. New chemical pathways may be engineered based on these biomanufactured products, leading to increased demand and larger scale production.

Table 2: Top 12 products from sugar fermentation (Werpy and Peterson 2004).

\begin{tabular}{|c|}
\hline Bullding Blocks \\
\hline 1,4 succinic, fumaric and malic acids \\
\hline 2,5 furan dicarboxylic acid \\
\hline 3 hydroxy propionic acid \\
\hline aspartic acid \\
\hline glucaric acid \\
\hline glutamic acid \\
\hline itaconic acid \\
\hline levulinic acid \\
\hline 3-hydroxybutyrolactone \\
\hline glycerol \\
\hline sorbitol \\
\hline xylitol/arabinitol \\
\hline
\end{tabular}

However, many of the processes to produce chemicals are not in commercial production, with the production of ethanol from fermentation being a notable exception (Hammerschlag 2006). Formation of lactic acid from corn dextrose is a million $\mathrm{kg} / \mathrm{year}$ industry in the US (Ragauskas et al. 2006), but still small scale in comparison with the production rates of commodity chemicals given in Table 1.

Fermentation of sugars is often aerobic, using bacteria, yeast or fungi. The synthesis routes are often not published, but some fermentation-based approaches that were reported in the roadmap include the oxaloacetate bioconversion in Kreb's cycle to give aspartic acid (both fermentation and enzymatic conversion pathways were considered), aerobic fungal fermentation of sugar to produce itaconic acid, and enzymatic transformation of sugar to give glycerol. Anaerobic processes can also be used, such as in the production of diacids and glutamic acid, and methane (which will be discussed later in the 
report).

Chemical transformation of sugars can take place by oxidation (e.g., of starch), oxidative dehydration (of C6 sugars), hydrogenation (sometimes acid-catalyzed) of cellulosics and sugars, acid amination, and esterification of oils. These products can be further converted by chemical means to derivatives: by oxidation (which tends to be less important for biomass as these compounds are already oxidized), hydrogenation and dehydration, bond cleavage and direct polymerization. Biological reactions to derivatives can also be made to work, with the advantages that they are generally enzymatic and so very selective, and may go directly from sugar to the end product. However, conditions must be mild, which may be difficult to achieve after a harsh pretreatment.

\subsubsection{Non-Sugar Fermentation}

Annual crops such as corn that have a high sugar yield are typically difficult to grow, and need fertilization, irrigation, herbicides and pesticides. In addition, these crops have been engineered for food production, rather than for efficiency of photosynthesis, or energy or chemicals production (Ragauskas et al. 2006). Mann (2004) has suggested that it would be more economical to work with waste biomass, or cellulosic crops such as perennials that are easy to grow over much of the US, because cellulose is the most abundant part of the plant. Use of cellulose from waste biomass would allow raw material to come from corn stalks (Thanakoses et al. 2003a), wood, bagasse from sugarcane (Thanakoses et al. 2003b), and even animal products (if proteins can be used). Research by Holtzapple has also considered fermentation of municipal waste. Chan and Holtzapple (2003), Aiello-Mazaarri and coworkers $(2005,2006)$, and Domke and coworkers (2004) have examined fermentation of industrial waste and paper to produce carboxylic acids.

Conversion of cellulose to fuel and hydrocarbons is a multistage process. The biomass must first be physically or chemically broken down, to separate the cellulose from other components, such as lignin. Pretreatment issues dominate cellulose and lignin processing, and often involve acid- or basecatalyzed hydrolysis to facilitate enzymatic breakdown. The costs of pretreatment are high, but some suggest (e.g., Mann 2004) that few major technical improvements in the chemical or acid processing are possible. However, pretreatment is an active area of research, one example being investigation of improvements in lime pretreatment (e.g., Chang and Holtzapple, 2000, Chang et al. 2001a, 2001b).

The US DOE through the office of EERE Biomass Program, is currently supporting means to improve the pretreatment of wood-based materials. This work, which could be applied to any of the biomass-based technologies, investigates improving the mechanical breakup of biomaterials into fine particles, which can then be fluidized and reacted. Many of these are engineering challenges to study the best means to transport biomass particulates from separators to reactors, and the effect of moisture content and particle size on reaction kinetics. A different approach to pretreatment issues is to use genomics and plant science to develop biomass crops with enhanced decomposition rates, such as those with cell walls more easily digested by bacteria (Ragauskas et al. 2006). Delignification of corn stover is actively being investigated by Holtzapple and coworkers (Kim and Holtzapple 2005, 2006a, 2006b).

Once isolated, the next step is the breakdown of cellulose to form sugars. The natural rotting process, facilitated by bacteria or fungi, is slow. Enzymatic hydrolysis will speed the process, but large facilities are required to sustain a reasonable throughput. The bacteria involved in the breakdown of cellulose consume a considerable amount of raw material, lessening efficiency. Byproducts are a problem when the processes of oxidation produce aldehydes and acids as well as sugars. Once produced, these sugars can be fermented and processed by conventional means. 
Hence, the key research needs for fermentation of biomass include developments in microbiology of bacteria that break down cellulose quickly. These bacteria, along with target crops, will be developed using genomics and DNA-modification technology. A goal could be to produce bacteria that increase the conversion rate of cellulose to sugar, from the current $5 \%$ to $50 \%$. Lowering the consumption of raw material by bacteria will also increase efficiencies. Other goals may be the investigation of different conversion pathways (i.e., such as developing a type of bacteria that uses parazoline). Lynd (1996) promotes a consolidated bioprocessing approach (CBP) that uses one bacterium to go straight from cellulose to ethanol. Bacteria that consume sugars from hemicellulose - a raw component of biomass are also desirable.

Separations are important in handling of the varied and variable biofeedstocks: separation of cellulose from lignin and other plant materials, and separations of byproducts after fermentation is complete. A separation step in itself may allow production of a value added chemical, such as the production of xylitol from the pretreatment of cellulose.

The use of black liquor left over from wood pulping has been a subject of research for over two decades. Black Liquor is lignin that has been separated from cellulose, mixed with water and the chemicals used for the separation. Black liquor has been used as fuel, but there has been research into production of value-added chemicals. For instance, caustic-catalyzed treatment of lignin will allow it to depolymerize into phenolic compounds, which can be hydrolyzed to form alkyl benzenes (Ragauskas et al. 2006). Another avenue of research has been to graft copolymers on the lignin. Depending on the monomer selected, a wide variety of materials may be created for different applications (Meister 2002). An ongoing DOE EERE supported project is attempting to separate esterified wood-fiber based polyesters using cyclone technology (personal communication D.D. Bruns, U. Tennessee Knoxville 2006). These efforts though, have not progressed beyond the research stage and are not ready for commercialization.

\subsection{PYROLYSIS}

A third means of extracting chemicals from biomass is through pyrolysis (Hallet et al. 2002). Biomass feedstocks can be wood wastes, bark, or other forest products. The products are oils, comprised of oxygenated organic compounds, and water. Pyrolysis is complex, incorporating both evaporation and combustion of a viscous and sticky fuel. The process involves the heating and vaporization of water, which takes a lot of energy, separation of more volatile components, microexplosions, and formation of a porous char or cenosphere from the heavy non-volatile components. Unlike direct combustion, pyrolysis occurs at high temperatures, $\sim 400^{\circ} \mathrm{C}$, and ignition temperature is $730^{\circ} \mathrm{C}$. 


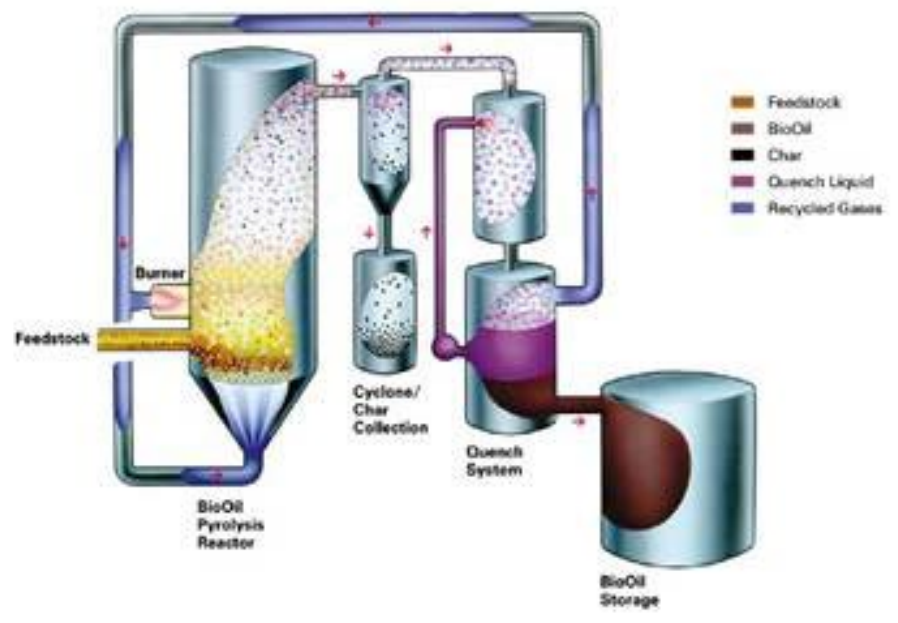

Fig. 7: Dynamotice's Patented Fast Pyrolysis Technology, reproduced here with permission from the Dynamotive webpage (http://www.dynamotive.com/en/technology/index.html).

A Canadian company, DynaMotive Corporation, http://www.dynamotive.com/ has established a plant that will manufacture 70 tons of BioOil from 100 tons of wood per day, with 20 tons of char and 10 tons of associated gases, Figure 7. Half of the BioOil will be used to generate electricity and half will be shipped to the US. The process involves heating the wood to $450-500^{\circ} \mathrm{C}$ in a bubbling fluidized bed reactor in the absence of oxygen. The plant will eventually be used to convert other biofeedstocks, such as bagasse and sawdust.

High temperature pyrolysis has been suggested as a more effective method of black liquor gasification than traditional lower temperature approaches because tarry residues are less of a problem. The tars, semi-volatiles and non-volatile char were identified from the heating of black liquor up to between 700 and $1,000^{\circ} \mathrm{C}$ (Sricharoenchaikul et al. 2002). A suite of aromatic compounds were observed, from single benzene rings up to pyrene and fluoranthrene (4-ring compounds). The authors suggested that the products from the high temperature pyrolysis are comparable to those created during the gasification of coal.

\subsection{SUMMARY}

Some of the aspects of biomass conversion to chemical feedstocks that require more investigation are listed below. Some of these research needs are already being investigated by the US DOE EERE. This list does not include the lengthy list of research requirements in plant science, genomics and microbiology, that have been outlined in more detail elsewhere (Ragauskas et al. 2006). However, with the exception of glycerine, the focus of government-sponsored investigations has not been on production of commodity chemicals from biological sources.

1. Biofeedstocks come from a variety of sources and have a wide range of physical and chemical properties. Biofeedstocks need improved thermal stability, so that chemical and physical transformation occurs under controlled conditions.

2. Pretreatment options for the breakdown of lignocellusics to produce lignin and sugars are being investigated by programs funded by the US DOE.

3. The cleanliness of syngas in chemical manufacture will affect the performance of syngas catalysts. This will set the requirements for pretreatment of biomaterials for thermochemical 
gasification. For example, feedstock purity is critical in the commercial production of lactic acid, and the production 1,3 propane diol (Ragauskas et al. 2006).

4. The infrastructure for separation of biomaterials (mechanical, chemical, air, steam) must be engineered to handle a variety of materials in the input stream. Biological feedstocks will have variable compositions, impurity levels, and moisture content. For instance, the US DOE Office of EERE supports research into renewable feedstocks, one example being the investigation of the effect of biomass moisture on size reduction in mechanical processing (http://www.eere.energy.gov/state_energy_program/grants_by_state.cfm/state=TN\#a200). Fluidization of a variety of particle-sizes is also being supported.

5. The feasibility of biological materials is being considered for their use as feedstocks in a conventional refinery or tandem process (involving mixed inputs or outputs). The physical properties of the biofeedstock will affect pretreatment and processing conditions. Biomass fractionation, which will depend on the characteristics of the crop being processed as well as the processing method, and separation methods are areas of research interest. Although this is an active area of research, there are products, such as glycerine, where biodiesel-derived material is already supplanting that from natural sources.

6. Research into fermentation of sugars is needed in the following areas: pathway engineering to increase efficiency, reduction of cost by increasing the mass transfer of oxygen and nutrients to participating microorganisms, direct production of derivatives, improved biocatalysts to reduce acid byproducts and increase yields, resistance to inhibitors, and the ability to handle a variety of sugar types. Solid catalysts that function well under messy fermentation conditions, are resistant to impurities, and are more robust and longer lived are desired. More selective catalysts are also needed. (Note that the catalyst technology for the production of oxygenates, such as ethanol, is well established.)

7. New bacterial strains are needed for faster cellulose breakdown, to be more efficient, or to generate a different chemical pathway (e.g., direct conversion of cellulose to ethanol). Hydrolysis of the fiber, oil, starch and protein fractions of crops needs to be better understood. Research activities will develop a better understanding of cell biology, metabolic pathways and enzyme functioning. Nutrients must be cheap, like corn liquor, not expensive, like biotin or yeast extract. The role of processes competing with fermentation, such as enzymatic oxidation, must also be understood.

8. Areas for research in the chemical processing of biological materials include:

a. new catalysts (longer lived, more robust, solid acidic substrates to replace liquid catalysts, heterogeneous catalysis, tolerance to inhibitory components)

b. milder oxidation, with less exotic oxidants, lower concentrations

c. milder reduction, management of acid salts

d. more selective hydrogenation, dehydration, reduction and oxidation processes, better yields

e. improvements to the direct polymerization process, control of branching, rates, condensation of polymers

f. better control of bond cleavage 
g. continuous rather than batch processing

h. new pathways, alcohols to acids, aldehydes to acids, alcohols to aldehydes, acids to alcohols, dehydration to lactones and anhydrides

9. Downstream recovery costs need to be reduced: by achieving a higher final titer, lower $\mathrm{pH}$ operation to remove need for neutralization, and optimized handling of wastes - primarily salts. Mixed sugar streams must be more effectively utilized, or else improved separations of sugars are required. Separations and purification processes need to be developed and optimized. Unwanted acid coproducts must be reduced, and uses need to be found for residual solids.

10. Finally, the economics and feasibility of different methods for production of chemicals from biobased feedstocks should be compared, (e.g., the manufacture of ethanol from the fermentation of sugar versus ethanol from the hydration of ethylene). One of the most important aspects is a reduction of costs to allow bio-based processes to be competitive with other technologies. Scale up of biologically-based processes is difficult, particularly for enzymatic or bacterial conversions. Complications to economic analysis are government protection of agriculture, or investment for energy security purposes. Hence, the feasibility of a particular process will vary over time, and geographic location (i.e., proximity to markets for products), as well as direct costs and sales of products (Gallagher et al. 2006).

\section{UNCONVENTIONAL NATURAL GAS}

Unconventional, or stranded natural gas is being evaluated as an alternative to alleviate current shortages in natural gas supply. Stranded, or unconventional, natural gas is that which is not easily transported from source to end use by pipeline, or is uneconomical to transport as a gas. Unconventional natural gas may come from a variety of sources: natural gas hydrates, stranded or geographically remote methane, such as that from sites in Alaska or the Rocky Mountains, coal bed methane, and methane from anaerobic fermentation such as occurs in landfills.

Conventional supplies of natural gas in the US are limited, although known reserves of conventional natural gas are abundant. Worldwide there is a 70 year supply $(180 \mathrm{TCM})$ of gas, $7 \mathrm{TCM}$ of that in Central and South America, 7 TCM in North America, 14 TCM in Africa, 14 TCM in Asia Pacific, 64 TCM in Europe and Eurasia, and 73 TCM in Middle East (Fleisch and Sills 2005). However, not all these reserves are currently available, and recent increased demand for natural gas has caused prices to increase to the point where methanol and ammonia production are no longer economical in North America. A report from the National Academy of Science Study (Doyle et al. 2004) on Hydrates says that there will be a shortfall in conventional and unconventional natural gas by 2020 .

The chemical industry uses $26 \%$ of the natural gas consumed in the US, and $75 \%$ of that is used for heat and power. Separation processes are especially energy intensive, particularly for the refining, forest products, and chemical industries. These three industries consume more natural gas for powering of separation processes than all of the other industries combined consume for both feedstock and power. If the chemical industry is faced with shortages in supply, the replacement of natural gas, or construction of small plants to take advantage of stranded methane may be a partial solution. 
Until recently, natural gas has been relatively inexpensive, and so technology for conventional use is well understood. Current world consumption is $260 \mathrm{bcfd}$. Hydrogen production from natural gas uses $12 \mathrm{bcfd}$ for ammonia production, 6 bcfd for refineries, and 3 bcfd in methanol production. The production of syncrude and methanol are particularly important to the chemical industry.

Gas from unconventional sources must be controlled, concentrated, or converted to a liquid form or stabilized in some manner, before being transported to the chemical manufacturer, power plant, or end user. An alternative to transporting the gas is to develop modular plants that can be scaled down so that the stranded methane could be used in situ. These modular plants could be small scale with microturbines, fuel cells, or distributed systems that could be incorporated into farms, mills, or remote settings. The conversion of methane to a liquid product, such as methanol, will allow easier transportation of materials from remote sites.

Liquid products can be made from natural gas through a syngas process. Some synthesis routes, such as the production of diesel fuel, are well understood (Renesme et al. 1992). Gas to liquid - (gas refinery to give syncrude) - is predicted to operate at $0.7 \mathrm{bcfd}$ in 2006 , to be ramped up to 4 bcfd by 2012. Syncrude may then be converted to clean diesel, jet fuel, n-paraffins, lubricants, naphtha, olefins, etc. One example of gas to liquids is the Fischer-Tropsch production of liquid fuels such as done by Sasol, or methanol to gasoline (MTG) done by Mobil (http://nzic.org.nz/ChemProcesses/energy/7D.pdf).

Methanol is a primary natural gas product of the Lurgi process, and is commercially produced in Trinidad (http://www.methanex.com/ourcompany/locations_trinidad.html). The 5,000 TPD Atlas plant is the biggest in the world, and has been operated by Methanex and BP since June 2, 2004. The Atlas and Titan plants in Trinidad produce $8 \%$ of world's methanol at \$100/ton methanol, at a rate cost competitive at $\$ 20 \mathrm{bbl}$ oil. Methanol can give rise to a number of building block chemicals.

- $\quad$ acetic acid,

- dimethyl ether,

- gasoline (MTG)

- formaldehyde,

- olefins (MTO, MTP)

- ethane and propane.

The UOP/Norsk technology reacts $\mathrm{CH}_{3} \mathrm{OH}$ at $425-500^{\circ} \mathrm{C}$ in contact with a SAPO-34 catalyst (lattice with 3.8 Angstrom holes) at a $99.5 \%$ conversion rate. The exothermic reaction is carried out in a fluidized bed reactor, giving a 75-80\% carbon yield in ethane and propane (byproducts are butanes, $\mathrm{C} 5+, \mathrm{C} 1-\mathrm{C} 4$ paraffins, water, oxygenates, coke, $\mathrm{H}_{2}, \mathrm{CO}_{\mathrm{x}}$ ). A first plant is planned for Nigeria (Eurochem/Nigeria), for a gas to polymers process, yielding 7,500 TPD methanol via MTO). http://www.uop.com

Demonstration of methanol to olefins (MTO) technology was carried out by the US DOE in the 1980's (Johnson et al. 1986). More recent research interest has been focused on improvement of catalysts (e.g., Song and Haw 2002). Industrial-scale technologies are under development by UOP/Norsk Hydro and Exxon Mobil. The Lurgi methanol-to-propylene (MTP) process is ready for licensing and implementation http://www.lurgi.de/english/nbsp/).

Rather than making methanol through an indirect route involving syngas, methanol can also be produced by direct oxidative conversion of methane over a catalyst. Because syngas production involves at least two process steps under very different conditions, a one step route will represent savings in operating and capital costs. However, improvements in yield and catalyst performance are 
needed before this technology is implemented commercially (Renesme et al. 1992).

Methane from anaerobic fermentation can be generated from animal manure, biomass (e.g., methane from grain stillage, http://www.lurgi.de/english/nbsp/), waste water digestion gas, sewage treatment, as well as from landfills. The potential for anaerobic fermentation to be a source of useable methane rather than a source of pollution, will require research into improvements in process control, operating efficiencies, and rate of digestion, targeting small-scale technologies that could use 10-300 Btu/cu of gas (Biomass Technical Advisory Committee 2003).

\section{HEAVY OIL}

Unconventional sources of petroleum include the Canadian Athabasca oil sand, Venezuelan heavy oil, and oil shale in the Western US. Historically, the relatively high cost of extraction of these hydrocarbons has been a major detriment to the use of heavy oil. These feedstocks are now more competitive due to the high prices of conventional resources.

The extraction of bitumen-derived crude (BDC) follows several steps. The first step is the extraction of the heavy oil from the rock. Tar sands ( $7 \%$ bitumen by weight from the tar sands) and oil shale contain relatively low concentrations of hydrocarbons. Some loss ( $<10 \%$ of bitumen) occurs the primary extraction process. Increased mechanical breakup or froth treatment can increase the yield. Current research is focused on making the extraction of unconventional crude more sustainable with less of an environmental impact, including better handling of mine tailings and the water entrained in the bitumen as it is extracted from the tar sands.

Placement of in situ cracking towers has been proposed for processing the bitumen. However, the physical and chemical properties of bitumen render it inherently unfriendly to standard refining methods, and the location of heavy oil and tar sands are far from the end users of hydrocarbon-based chemicals. So, the next practical step for the bitumen is to lower the viscosity and density of the fluid so that it can more easily be transported to a refinery. The process will also permit removal of some impurities and entrained water.

Alternative in-situ hydrocarbon production, as proposed for oil-shale deposits in the Western US, does not involve mining of the rock. Instead downhole combustion or gasification may be performed, which is predicted to give yields of up to 40-70\%. Development activities for another in-situ technology, steam assisted gravity drainage (SAGD), include design of reliable pumps and ways to recycle the water used in the steam process. One advantage of in situ production over traditional mining is that the product is ready for immediate refining.

Most of the BDC now goes to fuel production (65\% to sweet crude). However, many of the methods developed to extract hydrocarbons from the heavy gas oil (HGO) derived from bitumen are also appropriate to petrochemical manufacture. These include hydrocracking, fluidic carbon cracking (FCC), PetroFCC from UOP, deep catalytic cracking (DCC), and the catalytic pyrolysis process (CPP) $\$$ A key technical requirement for the use of heavy gas oil is development of new catalysts, such as that used for selective cycloparaffinic ring opening. These catalysts must be resistant to impurities such as sulfur and nitrogen-containing compounds, and coating with ultafine particles. Chemical processes that minimize the use of hydrogen are desirable, as this currently comes from

$\ddagger$ Chinese RIPP, Stone \& Webster 
natural gas.

Technology development in the processing of tar sands and heavy oils has been primarily done without DOE financial assistance. Tar sands work has been spearheaded by Canadian agencies (Canadian Energy Research Institute, The Alberta Research Council, The National Centre for Upgrading Technology, http://www.ncut.com/index.htm, Natural Resources Canada) and industries (Nova Chemicals Inc., Suncor Energy Inc., Shell Chemicals Canada, Petro-Canada).

\section{CONCLUSIONS}

The currently high prices for petroleum and natural gas have spurred the US chemical industry to evaluate alternative feedstocks for the production of commodity chemicals. These feedstocks include unconventional processing technologies, such as coal gasification and coal liquefaction, unconventional reserves such as stranded natural gas and heavy oil from tar sands or oil shale, and novel resources such as biomass. Because of recent interest in alternative fuels production, there are many recent reviews on the state of the art of alternative technologies. The use of alternative feedstocks for production of the highest volume commodity chemicals produced in the US has been evaluated in this report. Technical barriers for implementation have been identified. Current government-sponsored R\&D is focused on power generation or the production of transportation fuels. New pathways for commodity chemicals manufacture need to be developed using feedstock alternatives to petroleum and using sustainable manufacturing technologies.

There have been several assessments of the use of coal for generation of syngas and fuel liquids through Fischer-Tropsch process. Coal gasifiers are being run in the US, and new pilot gasification plants are being built for power production using clean coal technology. The most economical investment in new gasification facilities will be in combining the needs of electricity production and chemical manufacture. These initiatives will need investment in the development of methods of syngas storage and advanced control systems to switch from one activity to another. Other coal-based technologies, such as gas-toliquid plants, are being piloted around the world. Many of these initiatives are being done outside of North America in areas where petroleum is of limited supply to take advantage of regional supplies of coal. These plants are focused on fuel manufacture, but the lessons learned will be applicable to production of chemical building blocks. Syngas to fuels is being done by Sasol in South Africa, and China has invested in coal liquefaction to fuels.

Chemicals can be manufactured from biomass through gasification, pyrolysis, and fermentation in dedicated plants or in biorefineries. In general, the fermentation of sugar from crops such as corn and sugarcane will provide oxygenated organics, but these are often small volume niche chemicals with limited potential for large scale manufacture. Byproducts of transportation fuel production, such as biodiesel, may be used in bulk chemical manufacture - one example being glycerine. Efficient utilization of intermediate reagents such as these will require investment in the development of new synthesis pathways, or optimization of synthetic routes that are currently only being done in the laboratory. Research topics being explored on the bench scale and on the pilot scale include: biomass gasification, fermentation of sugars, decomposition of cellulose, separation of lignin and other plant components, high

temperature pyrolysis, and biorefining of wood and waste materials. Issues in use of replacement of petroleum by biomass feedstocks include impurities, and variabilities of feedstock composition, distributed supply, scalability and pathways for breakdown of cellulose.

Use of natural gas in the manufacture of methanol is being done offshore, but not in the US because of 
the high cost of natural gas. Conversion of stranded natural gas in situ at the wellhead to methanol may be the best route to capturing the potential of these resources. Methanol is a key building block chemical, and is easy to transport.

To date there has been little published on the use of heavy oil, oil shale, or tar sands for chemicals production because these sources of oil have only recently become cost competitive with natural gas and oil. In addition, the sources of unconventional crude oil are far from current petrochemical plants. Heavy oil, derived from tar sands in Canada, oil shale in Colorado, has a higher aromatic content than conventional crude. The key research aspect that needs to be addressed in the use of heavy oil for chemicals is the development of a ring opening catalyst to break down the polyaromatic tar compounds into smaller molecules.

Most of the work into alternative feedstocks that is available in the open literature has focused on energy production, either for electricity, liquid fuels from syngas, or bioethanol. Some technologies for chemicals production are mature, such as coal gasification, and are ready for implementation if economically feasible. Pilot plants have been run in the US and overseas. Other unconventional sources of organic compounds, such as ethanol from sugar fermentation and bitumen-derived heavy crude are now being exploited for fuels, rather than for chemical feedstocks. Use of biomass feedstocks for commodity chemical manufacture will require research and development in a variety of fields such as plant science, microbiology, genomics, catalysis, and chemical separations technologies. Scale-up and control of chemical plants must be considered. Published details of the use of alternative feedstocks in the production of commodity chemicals is primarily from academic studies, such as those done by Holtzapple and co-workers on biomaterials and the group of Olah on olefin synthesis.

In addition to the cost of replacement feedstocks and logistics, operational cost in chemical manufacture will be dominated by separations, as it is now. Efficient separation technologies are very important for industrial implementation of alternative-feedstock technologies, particularly biomass. In the case of biomass, solvent extraction is the most likely means by which feedstock preparation and impurity removal, byproduct elimination, and residue removal, will be accomplished. However, new processes and technologies may eventually be more effective and efficient, such as supercritical $\mathrm{CO}_{2}$, near critical $\mathrm{H}_{2} \mathrm{O}$, and gas-expanded liquids (Ragauskas et al. 2006).

The feedstock advantage that used to be enjoyed by US chemical manufacturers has now eroded to the point where methanol is no longer manufactured in North America. However, just as in other areas of the economy, such as in the replacement or augmentation of vehicle fuels, feedstock replacement is a high risk large investment. Some companies (e.g., Deutsch 2006) are investing heavily in alternative feedstocks. Other companies are less willing to gamble with a fluctuating price of oil, but control over feedstocks is of concern to all. Research into novel technologies supported by government programs will reduce the risk of transition of the US chemical industry into the post-oil period.

\section{REFERENCES}

Aiello-Mazzarri, C., Coward-Kelly, G., Agbogbo, F.K., Holtzapple, M.T. 2005. "Conversion of Municipal Solid Wastes into Carboxylic Acids by Anaerobic Countercurrent Fermentation - Effect of Using Intermediate Lime Treatment", Applied Biochemistry and Biotechnology 127(2), 79-93.

Aiello-Mazzarri, C., Agbogbo, F.K., Holtzapple, M.T. 2006. "Conversion of Municipal Solid Wastes into Carboxylic Acids Using a Mixed Culture of Mesophilic Microorganisms", Bioresource Technology 97(1), 47-56. 
Anderson, J. 2005. “On-Purpose Propylene Production”. In Technology and More, October 2005. UOP LLC 4488/10/05, p.1. www.uop.com

BCS Inc., 2006, "Coal as an Alternative Feedstock for Use in U.S. Manufacturing Industries", in progress.

Becker, P., "The Role of Synthetic Fuel in World War II Germany," Air University Review, JulyAugust 1981, online at http://www.airpower.maxwell.af.mil/airchronicles/aureview/1981/julaug/becker.htm.

Biomass Technical Advisory Committee. 2003. "Vision for Bioenergy and Biobased Products in the United States", http://www.bioproductsbioenergy.gov/pdfs/BioVision_03_Web.pdf, "Roadmap for Biomass Technologies in the United States”, http://www.bioproducts-bioenergy.gov/pdfs/FinalBiomassRoadmap.pdf.

Canadian Energy Research Institute. http://www.ceri.ca/

Chakrabartty, S.K., Selucky, M.L. 1985. "Characteristics of In Situ Coal Gasification Liquids from a Cretaceous Coal", Nature 316, 244-246.

Chan, W.N., Holtzapple, M.T. 2003. "Conversion of Municipal Solid Wastes to Carboxylic Acids by Thermophilic Fermentation”, Applied Biochemistry and Biotechnology 111(2), 93-112.

Chang, V.S., Holtzapple, M.T. 2000. "Fundamental Factors Affecting Biomass Enzymatic Reactivity", Applied Biochemistry and Biotechnology 84(6), 5-37.

Chang, V.S., Kaar, W.E., Burr, B., Holtzapple, M.T. 2001a. "Simultaneous Saccharification and Fermentation of Lime-Treated Biomass", Biotechnology Letters 23(16), 1327-1333.

Chang, V.S., Nagwani, M., Kim, C.H., Holtzapple, M.T. 2001b. "Oxidative Lime-Pretreatment of High-Lignin Biomass - Poplar Wood and Newspaper", Applied Biochemistry and Biotechnology (94)1, 1-28.

Chemical and Engineering News. 2006. "Glycerin Surplus", American Chemical Society, February 6, 2006, p. 7.

Coca, M.T., Mendez-Vigo, I., Elias, F.A. 1998. "Coal Gasification. Conception, Implementation and Operation of the ELCOGAS IGCC power plant", ELCOGAS, Madrid, Spain, January 1998. http://www.worldenergy.org/wec-geis/publications/default/tech_papers/17th_congress/2_3_13.asp

Consortium for Premium Carbon Products from Coal (CPCPC) - Penn State, W. Virginia, NETL, http://www.energy.psu.edu/cpcpc/overview.shtml

de Lange, T.J., Beeldman, M., Kiel, J.H.A., den Uil, H., Veenkamp, J.N. 2001. "Coproduction of fuels as an option for Demkolec?" ECN Biomass, ECN-C_-01-004, March 2001.

Deutsch, C.H. 2006. "Dupont Looking to Displace Fossil Fuels as Building Blocks of Chemicals", New York Times, February 28, 2006.

DOE/EIS-3057. "Draft EIS for the Gilberton Coal-to-Clean Fuels and Power Project", November 2005.

Domke, S.B., Aiello-Mazzarri, C., Holtzapple, M.T. 2004. "Mixed Acid Fermentation of Paper Fines and Industrial Biosludge", Bioresource Technology 91(1), 41-51.

Doyle, E.H. (chair). 2004. "Charting the Future of Methane Hydrate Research in the US", National Academy of Sciences, The National Academies Press, Washington, D.C., http://www.nap.edu

Energy Information Administration, February 2006, “Annual Energy Outlook 2006".

Ergo Energy, GE Power Systems. 2002. "The Chichilla IGCC Project to Date: Underground Coal Gasification and Environment". http://www.greencarcongress.com/2005/08/underground_coa.html.

Fleisch, T.H. and Sills, R.A., BP, "Innovation Day", Sept 7, 2005, Philadelphia

Foley, T., Anderson, J. 2005. "Methanol to Olefins (MTO)", In Technology and More, October 2005. UOP LLC 4488/10/05, p.3. www.uop.com

Gallagher, P., Schamel, G., Shapouri, H., Brubaker, H. 2006. "The International Competitiveness of the US Corn Industry: A Comparison with Sugar-Ethanol Processing in Brazil", Agribusiness 22(1), 109-134. 
Green, M.B. 2006. "Underground Coal Gasification- Its revival as a clean coal technology", ECOAL - October 2006.

Gregor, J., Anderson, J. 2005. "Propane Dehydrogenation (PDH)", In Technology and More, October 2005. UOP LLC 4488/10/05, p.2. www.uop.com.

Gregor, J., James, B. 2005. "Olefin Cracking”, In Technology and More, October 2005. UOP LLC 4488/10/05, p.4. www.uop.com.

Hallett, W.L.H., Clark, N.A., White, M. 2002. "Evaporation of Biomass Pyrolysis Oil Droplets II", Combust. Inst. (Canadian Sect.) 2002 Spring Technical Meeting.

Hammerschlag, R. 2006. "Ethanol's Energy Return on Investment: A Survey of the Literature 1990-Present”, Environ. Sci. Technol. 40, 1744-1750.

Hirsch, R.L., Bezdek, R., Wendling, R. 2006. "Peak of World Oil Production and Its Mitigation", AICHE Journal 52(1), 2-8.

International Dimethyl-ether Association. 2002. http://www.vs.ag/ida/idabrochure.pdf.

Johnson, D., Soto, J., Avidan, A., Gierlich, H., Thiagaraja, N. 1986. "Conversion of Methanol to

Gasoline Extended Project: Methanol to Olefins Modification and Operation of the Demonstration

Plant Milestone Report", DOE/ET-14914-H2.

Katzer, J. (Executive Director). 2007. "The Future of Coal", Massachusetts Institute of Technology, 2007.

Kim, S., Holtzapple, M.T. 2005. "Lime Pretreatment and Enzymatic Hydrolysis of Corn Stover", Bioresource Technology 96(18), 1994-2006.

Kim, S., Holtzapple, M.T. 2006a. "Effect of Structural Features on Enzyme Digestibility of Corn Stover", Bioresource Technology 97(4), 583-591.

Kim, S., Holtzapple, M.T. 2006b. "Delignification Kinetics of Corn Stover in Lime

Pretreatment”, Bioresource Technology 97(5), 778-785.

Kniel, L., Winter, O. 1984. "Ethylene", In Encyclopedia of Chemical Processing and Design, Volume 20, McKetta, J.J., Cunningham, W.A. (Eds). Marcel Dekker, Inc., New York, 80-159.

Lynd, L.R. 1996. "Overview and Evaluation of Fuel Ethanol from Cellulosic Biomass:

Technology, Economics, the Environment and Policy", Annual Review of Energy and the Environment 21, 403-465.

Mann. R. Nov. 2004. "Ethanol from Biomass", National Commission on Energy Policy.

Meister, J.J. 2002. "Modification of Lignin", J. Macromolecular Science - Polymer Reviews C42(2), 235-289.

National Energy Technology Laboratory,

http://www.netl.doe.gov/coalpower/gasification/description/gasifiers.html.

Nikolaisen, L. (Ed.), Nielsen, C., Larsen, M.G., Nielsen, V., Zielke, U., Kristensen, J.K., Christensen, B.H. 1998. "Straw for Energy Production: Technology, Environment, Economy", Copenhagen Center for Biomass Technology/Danish Energy Agency.

Olah, G.A. 2005. "Beyond Oil and Gas: The Methanol Economy", Angew. Chem. Int. Ed. 26362639.

Olah, G.A., Doggweiler, H., Feldberg, J.F., Frohlich, S., Gridinia, M.J., Karpeles, R., Keumi, T., Inaba, S-i., Ip, W.M., Lammertsma, K., Salem, G., Tabor, D.C. 1984. "Onium Ylide Chemistry 1. Bifunctional Acid-Base-Catalyzed Conversion of Heterosubstituted Methanes into Ethylene and Derived Hydrocarbons. The Onium Ylide Mechanism of the $\mathrm{C}_{1} \rightarrow \mathrm{C}_{2}$ Conversion", J. Am. Chem. Soc. 106, 2143-2149.

Priyadarsan, S., Annamalai, K., Sweeten, J.M., Muhktar, S., Holtzapple, M.T. 2004. "Fixed Bed Gasification of Feedlot Manure and Poultry Litter Biomass", Transactions of the ASAE 47(5), 16891696.

Priyadarsan, S., Annamalai, K., Sweeten, J.M., Holtzapple, M.T., Muhktar, S. 2005. “CoGasification of Blended Coal and Feedlot and Chicken Litter Biomass", Proceedings of the Combustion Institute 30, 2973-2980. 
Ragauskas, A.J., Williams, C.K., Davison, B.H., Britovsek, G., Caimey, J., Eckert, C.A., Frederick, W.J. Jr., Hallet, J.P., Leak, D.J., Liotta, C.L., Mielenz, J.R., Murphy, R., Templer, R., and T. Tschalpliski. 2006. "The Path Forward for Biofuels and Biomaterials." Science 311, 484-489.

Renesme, G., Saintjust, J. and Y. Muller. 1992. "Transportation Fuels and Chemicals Directly from Natural-Gas - How Expensive?”, Catalysis Today 13(2-3), 371-380.

Research Reports International. 2006. "Commercialization of Coal-to-Liquids Technology", November 2006.

Shenhua Group Corporation, http:/www.htigrp.com/data/upfiles/pdf/DCL\%20Technology\%2023Feb05.pdf.

Simbeck, D.R. 2001. " $\mathrm{CO}_{2}$ Mitigation Economics for Existing Coal Fired Power Plants".

Pittsburg Coal Conference, Dec. 4, Newcastle, New South Wales, Australia.

Söderberg, D.J. 2004. Vision 2020 Steering Team Priority Research Brainstorming Session, Dec. $1,2004$.

Song, W., Haw. J.F. 2003. "Improved Methanol to Olefin Catalyst with Nanocages

Functionalized through Ship-in-a-Bottle Synthesis from $\mathrm{PH}_{3}$ ", Angewandte Chemie International Edition 42(8) 892-894.

Spath, P., Dayton, D. 2003. "Preliminary Screening - Technical and Economic Assessment of Synthesis Gas to Fuels and Chemicals with Emphasis on the Potential for Biomass-Derived Syngas. NREL Technical Report NREL/TP-510-34929. Dec 2003.

Sricharoenchaikul, V., Frederick, Jr., Wm.J., Agrawal, P. 2002. "Black Liquor Gasification Characteristics. 2. Measurement of Condensable Organic Matter (Tar) at Rapid Heating Conditions", Ind. Eng. Chem. Res. 41, 5650-5658.

Thanakoses, P., Black, A.S., Holtzapple, M.T. 2003a. "Fermentation of Corn Stover to

Carboxylic Acids", Biotechnology and Bioengineering 83(2), 191-200.

Thanakoses, P., Mostafa, N.A.A., Holtzapple, M.T. 2003b. "Conversion of Sugarcane Bagasse to Carboxylic Acids Using a Mixed Culture of Mesophilic Microorganisms", Applied Biochemistry and Biotechnology 105, 523-546.

United Kingdom Department of Trade and Industry. 1999. "Technology Status Report, Coal Liquefaction", TSR010, Oct. 1999.

United States Department of Energy, Office of Energy Efficiency and Renewable Energy. 2005. $27^{\text {th }}$ Symposium on Biotechnology for Fuels and Chemicals. http://www.eere.energy.gov//biomass/biotech symposium/

United States Department of Energy, Office of Energy Efficiency and Renewable Energy. 2003. "DOE Thermochemical Users Facility", DOE/GO-102003-1783, November 2003.

United States Department of Energy. 1997. "Clean Coal Technology Project Produces First Methanol from Coal”. http://www.netl.doe.gov/publications/press/1997/tl kngs.html, Techline May 201997.

Werpy, T., Peterson, G., Eds. 2004. "Top Value Added Chemicals from Biomass, Volume I: Results of Screening for Potential Candidates from Sugars and Synthesis Gases", Pacific Northwest National Laboratory, National Renewable Energy Laboratory, DOE Office of Biomass Program, Energy Efficiency Renewable Energy, August 2004.

Wham, R.M., Fisher, J.F., Forrestoer, R.C., III, Irvine, A.R., Salmon, R., Singh, S.P.N., Ulrich. W.C. 1981. "Liquefaction Technology Assessment. Phase 1: Indirect Liquefaction of Coal to Methanol and Gasoline Using Available Technology", Oak Ridge National Laboratory ORNL-5664.

Wham, R.M. "Stability of Short-Contact-Time Coal Liquefaction Products". Oak Ridge National Laboratory ORNL/TM-8651.

Williams, R.H. 2004a. "Towards Polygeneration of Fluid Fuels and Electricity via Gasification of Coal and Biomass", National Commission for Energy Policy. November, http://www.energycommission.org/research/

Williams, R.H. 2004b. "IGCC Next Step on the Path to Gasification-Based Energy from Coal", 
National Commission for Energy Policy. November, http://www.energycommission.org/research/ Zhang, H.L., He, Y. Li., S., Liu, X.B. 2005. "Synthesis and Hydrolytic Degradation of Aliphatic Polyester Amides", Polymer Degradation and Stability 88(2), 309-316. 

Appendix A

LARGE VOLUME CHEMICALS MANUFACTURED IN THE UNITED STATES 




\section{Appendix A. LARGE VOLUME CHEMICALS MANUFACTURED IN THE UNITED STATES}

Table 3. Large volume chemicals manufactured in the United States

\begin{tabular}{|c|c|c|c|}
\hline Chemical & $\begin{array}{l}\text { Volume of } \\
\text { production } \\
10^{6} \text { tons } \\
\text { (US, 1997) }\end{array}$ & $\begin{array}{l}\text { Alternative feedstock or } \\
\text { precursor }\end{array}$ & Industry/product \\
\hline $\begin{array}{l}\text { Olefins: } \\
\text { Ethylene } \\
\text { Propylene } \\
\text { Butadiene }(1,3-)\end{array}$ & $\begin{array}{l}24.125 \\
14.350 \\
2.038 \\
\end{array}$ & $\begin{array}{l}\text { Gasification of coal, } \\
\text { biomass, DME* } \\
\text { Methanol (MTO*, } \\
\text { MTP*) }\end{array}$ & Gas to polymers \\
\hline Ammonia & 14.204 & $\begin{array}{l}\text { Gasification of coal, } \\
\text { biomass } \\
\text { Natural gas, Haber cycle }\end{array}$ & Fertilizer, reagent, explosives \\
\hline $\begin{array}{l}\text { Chlorinated organics } \\
\text { Ethylene dichloride } \\
\text { Vinyl chloride } \\
\text { Methyl chloride }\end{array}$ & $\begin{array}{l}10.088 \\
8.763 \\
0.563\end{array}$ & Chlorination of olefins & $\begin{array}{l}\text { Polyurethanes, solvents, pulp } \\
\text { and paper solvents, }\end{array}$ \\
\hline MTBE & 9.038 & $\mathrm{CH}_{3} \mathrm{OH}+$ isobutylene & Fuel additive \\
\hline $\begin{array}{l}\text { Aromatics: } \\
\text { Benzene } \\
\text { Ethylbenzene } \\
\text { Toluene } \\
\text { P-xylene } \\
\text { Cumene } \\
\end{array}$ & $\begin{array}{l}7.463 \\
6.950 \\
4.138 \\
3.963 \\
2.913 \\
\end{array}$ & $\begin{array}{l}\text { Gasification of coal, } \\
\text { biomass } \\
\text { From methanol from } \\
\text { GTL* } \\
\text { Friedel-Crafts alkylation }\end{array}$ & Polymerization/surfactants \\
\hline Methanol & 6.013 & $\begin{array}{l}\text { Gasification of coal, } \\
\text { biomass } \\
\text { FT }\end{array}$ & Building block \\
\hline Urea & 5.918 & Ammonia, $\mathrm{CO}_{2}$ & Fertilizer, resins, adhesives \\
\hline Styrene & 5.700 & ethylbenzene & polystyrene \\
\hline Terephthalic acid & 5.000 & p-xylene & intermediate \\
\hline $\begin{array}{l}\text { Aldehydes } \\
\text { Formaldehyde }\end{array}$ & 4.188 & $\begin{array}{l}\text { From methanol (natural } \\
\text { gas) }\end{array}$ & Building block for olefins \\
\hline $\begin{array}{l}\text { Oxygenated organics } \\
\text { Ethylene oxide } \\
\text { Propylene oxide }\end{array}$ & $\begin{array}{l}3.550 \\
1.963\end{array}$ & $\begin{array}{l}\text { Gasification of coal, } \\
\text { biomass, through } \\
\text { ethylene oxide }\end{array}$ & Building block, reagent \\
\hline $\begin{array}{l}\text { Ethylene glycol } \\
\text { Propylene glycol }\end{array}$ & $\begin{array}{l}2.813 \\
0.538 \\
\end{array}$ & $\begin{array}{l}\text { Hydration of ethylene } \\
\text { oxide }\end{array}$ & polyester \\
\hline $\begin{array}{l}\text { Carboxylic acids: } \\
\text { Acetic acid and anhydride }\end{array}$ & 2.425 & $\begin{array}{l}\text { Gasification of coal, } \\
\text { biomass, } \\
\text { Methanol from syngas }\end{array}$ & $\begin{array}{l}\text { Adds } C_{2} \text {, reagents and } \\
\text { intermediates }\end{array}$ \\
\hline $\begin{array}{l}\text { Phenol } \\
\text { Bis phenol A }\end{array}$ & $\begin{array}{l}2.175 \\
0.863\end{array}$ & Cumene & $\begin{array}{l}\text { Resins, paints, adhesives, } \\
\text { coatings, solvents, } \\
\text { polycarbonate }\end{array}$ \\
\hline Acrylonitrile & 1.663 & $\mathrm{NH}_{3}+$ propylene/propane & Acrylic fibers \\
\hline Chemical & $\begin{array}{l}\text { Volume of } \\
\text { Production } \\
10^{6} \text { tons } \\
(\mathrm{US}, 1997) \\
\end{array}$ & $\begin{array}{l}\text { Alternative Feedstock } \\
\text { or precursor }\end{array}$ & Industry/Product \\
\hline $\begin{array}{l}\text { Esters } \\
\text { Vinyl acetate } \\
\text { Methyl methacrylate }\end{array}$ & $\begin{array}{l}1.500 \\
0.313\end{array}$ & From ethylene & $\begin{array}{l}\text { Intermediate } \\
\text { Coatings, plastics }\end{array}$ \\
\hline
\end{tabular}




\begin{tabular}{|l|l|l|l|}
\hline Chemical & $\begin{array}{l}\text { Volume of } \\
\text { production } \\
\mathbf{1 0}^{\mathbf{6}} \text { tons } \\
\text { (US, 1997) }\end{array}$ & $\begin{array}{l}\text { Alternative feedstock or } \\
\text { precursor }\end{array}$ & Industry/product \\
\hline Acetone & 1.463 & $\begin{array}{l}\text { Gasification of coal, } \\
\text { biomass, BTEX }\end{array}$ & Intermediate \\
\hline Cyclohexane & 1.100 & $\begin{array}{l}\text { Hydrogenation of } \\
\text { benzene }\end{array}$ & intermediate \\
\hline Caprolactam & 0.825 & Oxidation of cyclohexane & nylon \\
\hline Aniline & 0.713 & Nitro or chlorobenzene & intermediate \\
\hline $\begin{array}{l}\text { Isopropyl alcohol } \\
\text { Butanol }\end{array}$ & 0.700 & $\begin{array}{l}\text { Gasification of coal, } \\
\text { biomass, propylene }\end{array}$ & intermediate \\
\hline
\end{tabular}

Table 4. Specialty chemicals, chemicals with development potential

\begin{tabular}{|c|c|c|}
\hline Adipic acid & Reacted with glycerol & Polymeric intermediate \\
\hline Ascorbic acid & Kreb's cycle & Building block \\
\hline Diacids & fermentation & $\begin{array}{l}\text { Replace petrochemical maleic } \\
\text { acid, polymers }\end{array}$ \\
\hline Aspartic acid & $\begin{array}{l}\text { Amination of fumaric } \\
\text { acid, or enzymatic } \\
\text { conversion }\end{array}$ & Amino C4 acids, polymers \\
\hline Itaconic acid & $\begin{array}{c}\text { Fungal fermentation of } \\
\text { sugar }\end{array}$ & Specialty monomer \\
\hline $\begin{array}{l}\text { FCDA 2,5 furan } \\
\text { dicarboxylic acid }\end{array}$ & $\begin{array}{c}\text { Oxidative dehydration of } \\
\text { sugar }\end{array}$ & Polyethylene terphthalate \\
\hline Glutaric acid & Oxidation of starch & $\begin{array}{l}\text { Building block from } \\
\text { carbohydrate }\end{array}$ \\
\hline Levulinic acid & $\begin{array}{l}\text { Dehydration of } \\
\text { cellulosics, sugars }\end{array}$ & $\begin{array}{l}\text { Building block from } \\
\text { carbohydrate }\end{array}$ \\
\hline $\begin{array}{c}\text { HPA - hydroxy propionic } \\
\text { acid }\end{array}$ & fermentation & Acrylates, malonic acid, diol \\
\hline Xylitol & Pretreatment of celluose & $\begin{array}{c}\text { Xylaric, arabonic aicds, } \\
\text { polymers }\end{array}$ \\
\hline Sorbitol & $\begin{array}{l}\text { Hydrogentaion of } \\
\text { glucose }\end{array}$ & $\begin{array}{l}\text { Polymers, propylene glycol, } \\
\text { lactic acid, polysaccharides }\end{array}$ \\
\hline Hydroxybutyrolactone & Oxidation of starch & Furans, polymers \\
\hline
\end{tabular}

Table 5. Fuels, Hydrocarbons

\begin{tabular}{|l|l|l|}
\hline $\begin{array}{l}\text { Paraffins: } \\
\text { Ethane } \\
\text { propane } \\
\text { butanes }\end{array}$ & $\begin{array}{l}\text { Gasification of coal, } \\
\text { biomass } \\
\text { Methanol } \\
\text { dehydrogenation } \\
\text { FT* liquid }\end{array}$ & Fuel, building block \\
\hline Ethanol & $\begin{array}{l}\text { Fermentation of biomass } \\
\text { Gasification of coal, } \\
\text { biomass }\end{array}$ & fuel \\
\hline $\begin{array}{l}\text { Biodiesel, } \\
\text { Glycerol }\end{array}$ & $\begin{array}{l}\text { Enzymatic } \\
\text { transformation of } \\
\text { biomass } \\
\text { Transesterification of oils }\end{array}$ & $\begin{array}{l}\text { Fuel, } \\
\text { Building block } \\
\text { Polyurethane, glycol, } \\
\text { 1-propane diol, biodiesel }\end{array}$ \\
\hline Dimethyl ether & & Replacement for propane \\
\hline
\end{tabular}


A-5 



\section{INTERNAL DISTRIBUTION}

1. D.W. DePaoli

2. R. Hawsey

3. C.A. Blue

4. J. McFarlane

5. I.G. Wright
6. S.M. Robinson

7. R. Wham

8. J.R. Mielenz

9. ORNL Office of Technical Information and Classification 